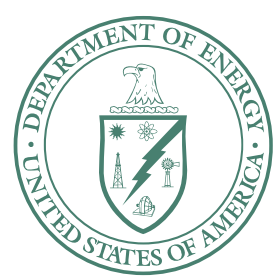

U.S. Department of Energy

Idaho Operations Office

\title{
Removal Action Plan for the Accelerated Retrieval Project for a Described Area within Pit 4
}

August 2006 
DOE/NE-ID-11178

Revision 2

Project No. 23927

\section{Removal Action Plan for the Accelerated Retrieval Project for a Described Area within Pit 4}

August 2006

Prepared for the 



\begin{abstract}
This Removal Action Plan documents the plan for implementation of the Comprehensive Environmental Response, Compensation, and Liability Act non-time-critical removal action to be performed by the Accelerated Retrieval Project. The focus of the action is the limited excavation and retrieval of selected waste streams from a designated portion of the Radioactive Waste Management Complex Subsurface Disposal Area that are contaminated with volatile organic compounds, isotopes of uranium, or transuranic radionuclides. The selected retrieval area is approximately 0.2 ha (1/2 acre) and is located in the eastern portion of Pit 4 . The waste in this area is primarily from the Rocky Flats Plant in Colorado. The area was selected by the U.S. Department of Energy, State of Idaho Department of Environmental Quality, and U.S. Environmental Protection Agency based on inventory evaluations identifying significant quantities of transuranic and other contaminated waste disposed of in the area. The proposed project is referred to as the Accelerated Retrieval Project. This Removal Action Plan details the major work elements, operations approach, and schedule, and summarizes the environmental, safety and health, and waste management considerations associated with the project.
\end{abstract}




\section{CONTENTS}

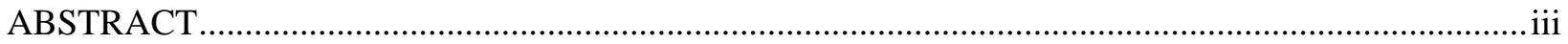

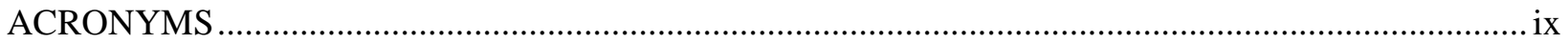

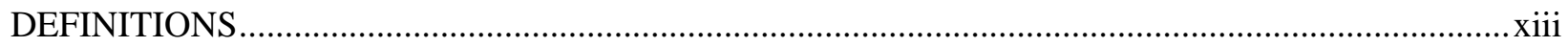

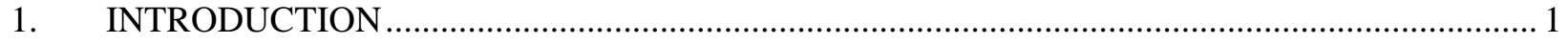

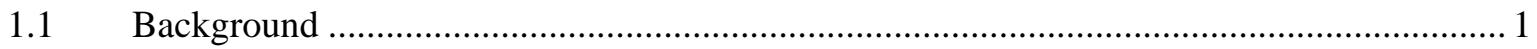

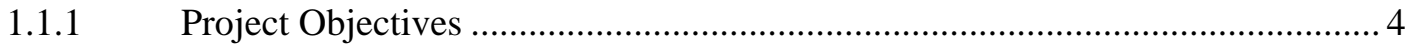

1.1.2 Background of Pit 4 within the Subsurface Disposal Area .................................. 4

1.1.3 Estimated Waste Inventory in the Designated Retrieval Area of Pit 4 ............... 5

$1.2 \quad$ Accelerated Retrieval Project Overview …................................................................... 7

1.2.1 Accelerated Retrieval Project Facilities ..................................................... 8

2. REMOVAL ACTION WORK ELEMENTS ….................................................................... 11

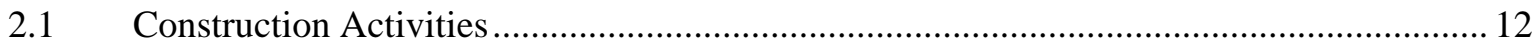

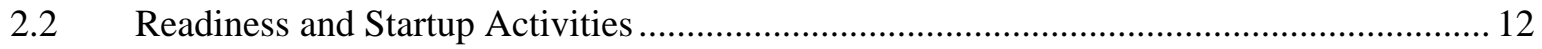

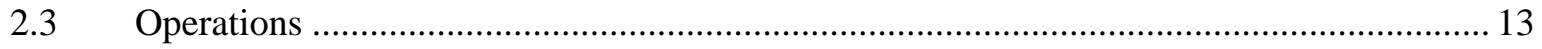

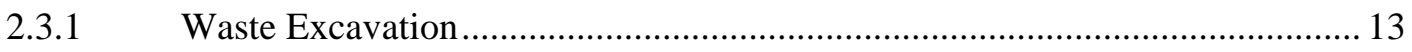

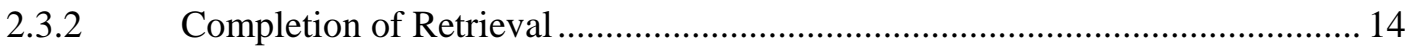

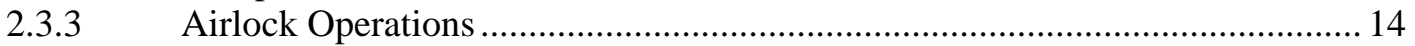

2.3.4 Container Storage ..................................................................................... 15

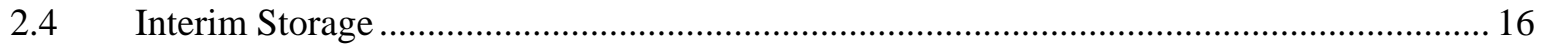

2.5 Waste Isolation Pilot Plant Interface Activities............................................................ 16

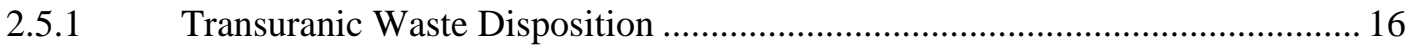

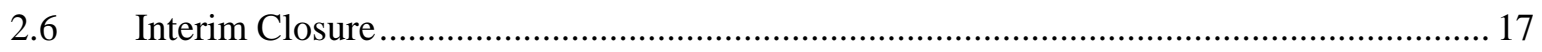

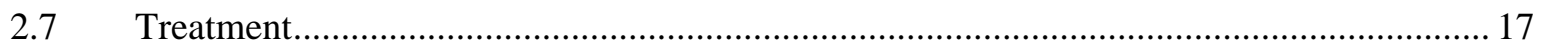

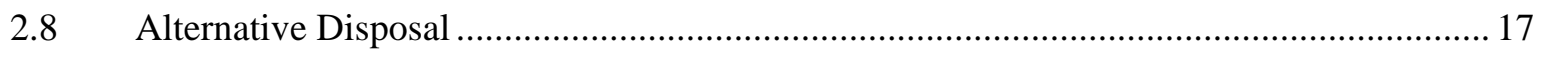

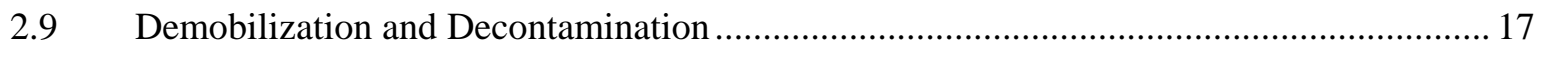

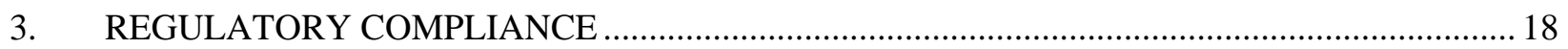

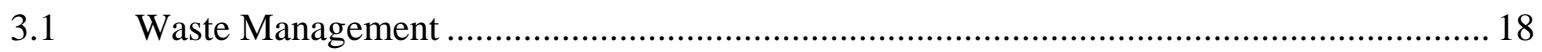

3.1.1 Waste Management Assumptions and Regulatory Considerations.................... 18 


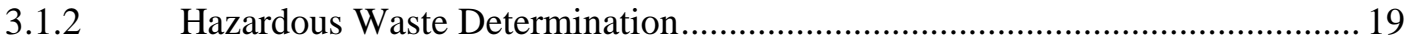

3.1.3 Preliminary Hazardous Waste Numbers ........................................................... 19

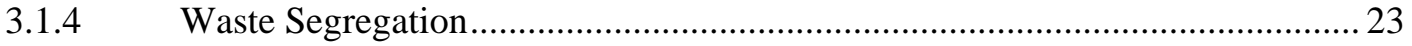

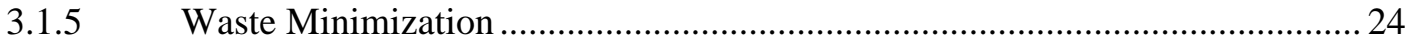

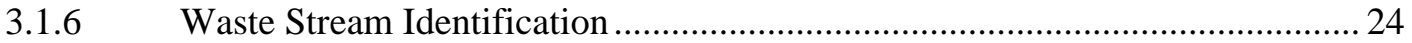

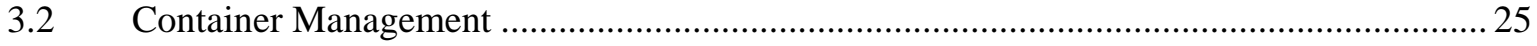

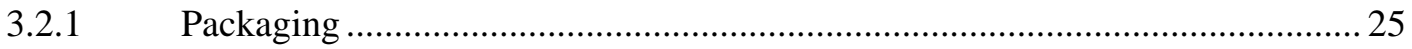

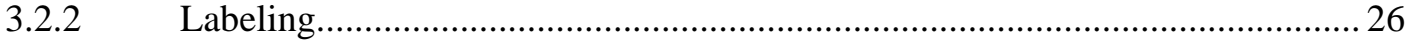

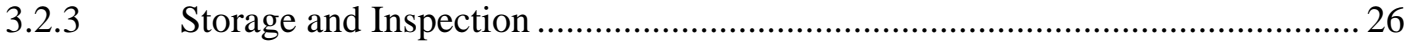

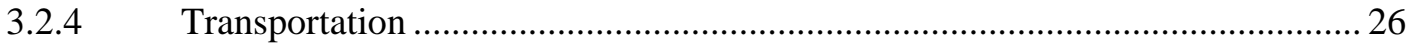

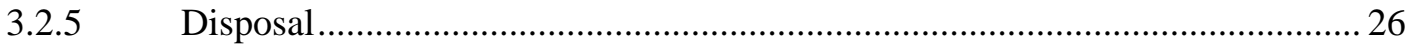

3.3 Applicable or Relevant and Appropriate Requirements ................................................. 27

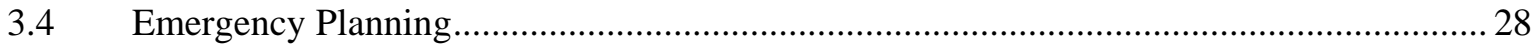

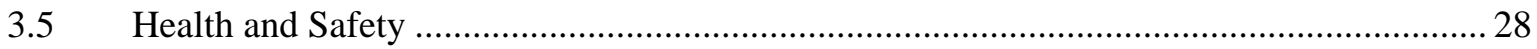

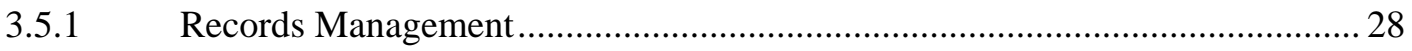

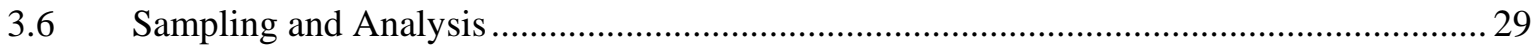

3.6.1 Sampling Requirements for Waste Isolation Pilot Plant Characterization.........29

3.6.2 Sampling of Nontargeted Waste Remaining in Pit 4 and Underburden............. 29

4. NON-TIME-CRITICAL REMOVAL ACTION SCHEDULE ................................................... 30

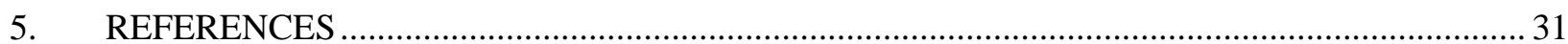

Appendix A—Applicable or Relevant and Appropriate Requirements.................................................. 39

Appendix B-Waste Acceptance Criteria for WMF-698 ….................................................................. 55

Appendix C—Waste Stream Summary for the Accelerated Retrieval Project......................................... 61

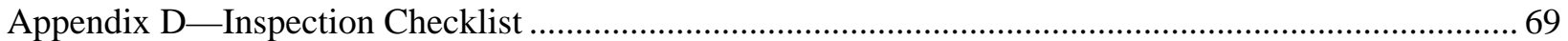




\section{FIGURES}

1. Location of the Radioactive Waste Management Complex and other major facilities within the Idaho National Laboratory Site ................................................................................................. 2

2. $\quad$ Pit 4 and the Retrieval Enclosure at the Subsurface Disposal Area ............................................... 3

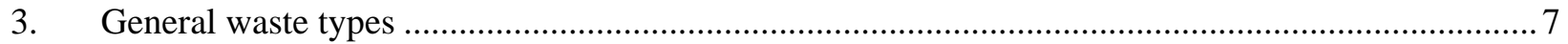

4. Depiction of the Retrieval Enclosure, showing the two attached airlocks and the retrieval area ....... 9

5. Depiction of WMF-698, showing an example of containers stored in the modified dense pack

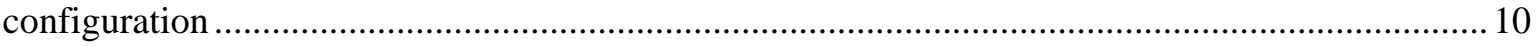

6. Artist rendition of typical drum packaging station (safety features, such as the safety railing, are not depicted).

\section{TABLES}

1. Rocky Flats Plant waste content in the designated retrieval area of Pit 4 within the Subsurface Disposal Area 


\section{ACRONYMS}

AK

AOC

ARP

ARAR

CCP

CERCLA Comprehensive Environmental Response, Compensation, and Liability Act

CFR Code of Federal Regulations

DD\&D deactivation, decontamination, and decommissioning

DEQ Idaho Department of Environmental Quality

DOE U.S. Department of Energy

DOE-ID U.S. Department of Energy Idaho Operations Office

DQO data quality objective

EDF engineering design file

EE/CA engineering evaluation/cost analysis

EPA U.S. Environmental Protection Agency

EP/CP emergency plan/contingency plan

FGE fissile gram equivalent

HASP health and safety plan

HEPA high-efficiency particulate air

HWD hazardous waste determination

HWMA Hazardous Waste Management Act

HWN hazardous waste number

ICDF Idaho CERCLA Disposal Facility

ICP Idaho Cleanup Project

IDAPA Idaho Administrative Procedures Act 


\begin{tabular}{|c|c|}
\hline INL & Idaho National Laboratory \\
\hline IW & industrial waste \\
\hline IWTS & Integrated Waste Tracking System \\
\hline LDR & land disposal restriction \\
\hline MCP & management control procedure \\
\hline MTRU & mixed transuranic \\
\hline NTCRA & non-time-critical removal action \\
\hline NTW & nontargeted waste \\
\hline OU & operable unit \\
\hline PCB & polychlorinated biphenyl \\
\hline PCS & potentially contaminated soil \\
\hline PPE & personal protective equipment \\
\hline RAP & Removal Action Plan \\
\hline RCRA & Resource Conservation and Recovery Act \\
\hline $\mathrm{RE}$ & Retrieval Enclosure \\
\hline RFP & Rocky Flats Plant \\
\hline ROD & record of decision \\
\hline RWMC & Radioactive Waste Management Complex \\
\hline SDA & Subsurface Disposal Area \\
\hline SLRA & screening level risk assessment \\
\hline TBC & to-be-considered \\
\hline TRU & transuranic \\
\hline TSCA & Toxic Substances Control Act \\
\hline TW & targeted waste \\
\hline UW & universal waste \\
\hline VOC & volatile organic compound \\
\hline
\end{tabular}


WAC waste acceptance criteria

WAG waste area group

WGS Waste Generator Services

WIPP Waste Isolation Pilot Plant 


\section{DEFINITIONS}

Acceptable knowledge. Includes information on the process generating the waste, waste packaging information, physical descriptions of the waste, radiological monitoring data, and other pertinent information gathered from records produced at the time the waste was generated or at a later time. The acceptable knowledge for the waste in Pit 4 was combined in a document entitled Historical Background Report for Rocky Flats Plant Waste Shipped to the INEEL and Buried in the SDA from 1954 through 1971 (ICP 2005).

Area of contamination. For the purpose of this non-time-critical removal action, the area of contamination encompasses the Subsurface Disposal Area as bounded by the flood control dike that surrounds the Subsurface Disposal Area perimeter.

Nontargeted waste. Includes debris, combustible waste, noncombustible waste, and Series 742 and 744 sludges that will remain in or are consolidated and relocated within the trench during the removal action.

Pyrophoric. For this document, material that fails Test N.2 defined by the United Nations, Manual of Tests and Criteria (UN 2005), and referenced by the Department of Transportation, 49 CFR 173.124, and DOE/ID-10381 (DOE-ID 2005a)

Retrieved waste. Waste that is removed from the designated area of Pit 4 during the Accelerated Retrieval Project.

Secondary waste. A generic category for waste generated from support activities related to retrieving, processing, sampling, and packaging Accelerated Retrieval Project retrieved waste. Examples of secondary waste include waste from decontamination activities, personal protective equipment from maintenance and operations, and used equipment and sampling materials. Secondary waste is generated during all project phases.

Targeted waste. Targeted waste in Pit 4 includes graphite, filters, Series 741 and 743 sludge, and uranium roaster oxide waste that are to be retrieved and removed from Pit 4 during the removal action.

Transuranic radionuclides. Radionuclides with an atomic number greater than 92.

Transuranic waste. Without regard to source or form, waste that is contaminated with alpha-emitting transuranic radionuclides (atomic number greater than 92) with half-lives greater than 20 years and concentrations greater than $100 \mathrm{nCi} / \mathrm{g}$ at the time of assay. Primary radionuclides associated with Subsurface Disposal Area Rocky Flats Plant transuranic waste are $\mathrm{Pu}-238, \mathrm{Pu}-239, \mathrm{Pu}-240, \mathrm{Pu}-242$, and Am-241. 


\section{Removal Action Plan for the Accelerated Retrieval Project for a Described Area within Pit 4}

\section{INTRODUCTION}

This Removal Action Plan (RAP) documents the plan for implementation of the Comprehensive Environmental Response, Compensation, and Liability Act (CERCLA) non-time-critical removal action (NTCRA) to be performed by the Accelerated Retrieval (ARP). The NTCRA involves the limited excavation and retrieval of selected waste streams from a designated portion of the Subsurface Disposal Area (SDA) within the Radioactive Waste Management Complex (RWMC) at the Idaho National Laboratory (INL) Site that are contaminated with volatile organic compounds (VOCs), isotopes of uranium, or transuranic (TRU) radionuclides. The approximate 0.2 -ha (1/2-acre) designated portion is located within Pit 4. The RWMC location at the INL Site is illustrated in Figure 1. The designated retrieval area is shown in Figure 2. This area was selected by the U.S. Department of Energy (DOE), State of Idaho Department of Environmental Quality (DEQ), and U.S. Environmental Protection Agency (EPA) based on inventory evaluations, which identified significant quantities of TRU-contaminated Rocky Flats Plant (RFP) waste disposed of within the area. This RAP details the major work elements, operations approach, and schedule details, and summarizes the environmental and waste management considerations associated with the project.

Revision 1 to the RAP was made to document changes to project planning that arose during the initial months of project operations and from U.S. Department of Energy Idaho Operations Office (DOE-ID) contractor transition. The primary changes made in Revision 1 included adding CERCLA waste storage areas and updating waste management planning details, such as an update to the acceptable knowledge (AK) information. At the time of Revision 1, project operations had been ongoing for approximately 4 months. Revision 2 is being prepared primarily to support needed modifications of the Waste Acceptance Criteria (Appendix B) and to include operational turnover of WMF-628 to the Advanced Mixed Waste Treatment Project.

This proposed NTCRA was described in the Engineering Evaluation/Cost Analysis for the Accelerated Retrieval of a Designated Portion of Pit 4 (EE/CA) (DOE-ID 2004a). The EE/CA was reviewed and commented on by the public. An Action Memorandum for Accelerated Retrieval of a Described Area within Pit 4 (DOE-ID 2004b) was prepared by DOE-ID, and received the concurrence of DEQ and Region 10 EPA. The Action Memorandum provides additional detail (in comparison to the EE/CA) regarding the proposed removal action and documents DEQ and EPA concurrence with performance of the NTCRA. The proposed removal action, in addition to addressing a portion of the hazardous substances in the SDA, will provide characterization, technical, and cost information from full-scale waste retrieval activities that will support the Remedial Investigation/Feasibility Study for Operable Unit (OU) 7-13/14.

\subsection{Background}

This section provides general background information for the ARP, including a summary of the project objectives that were developed in the EE/CA. 


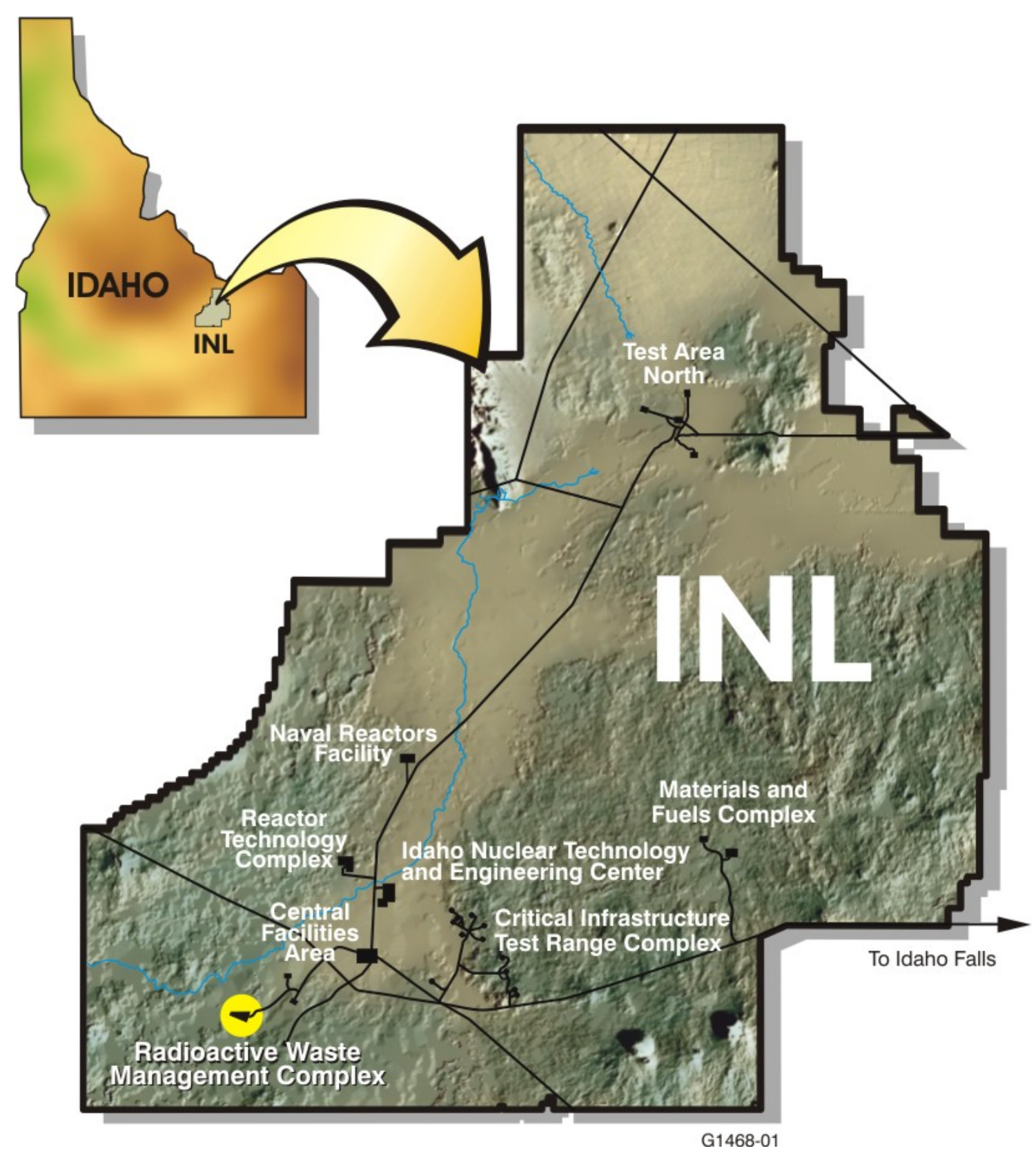

Figure 1. Location of the Radioactive Waste Management Complex and other major facilities within the Idaho National Laboratory Site. 


\section{Subsurface Disposal Area}

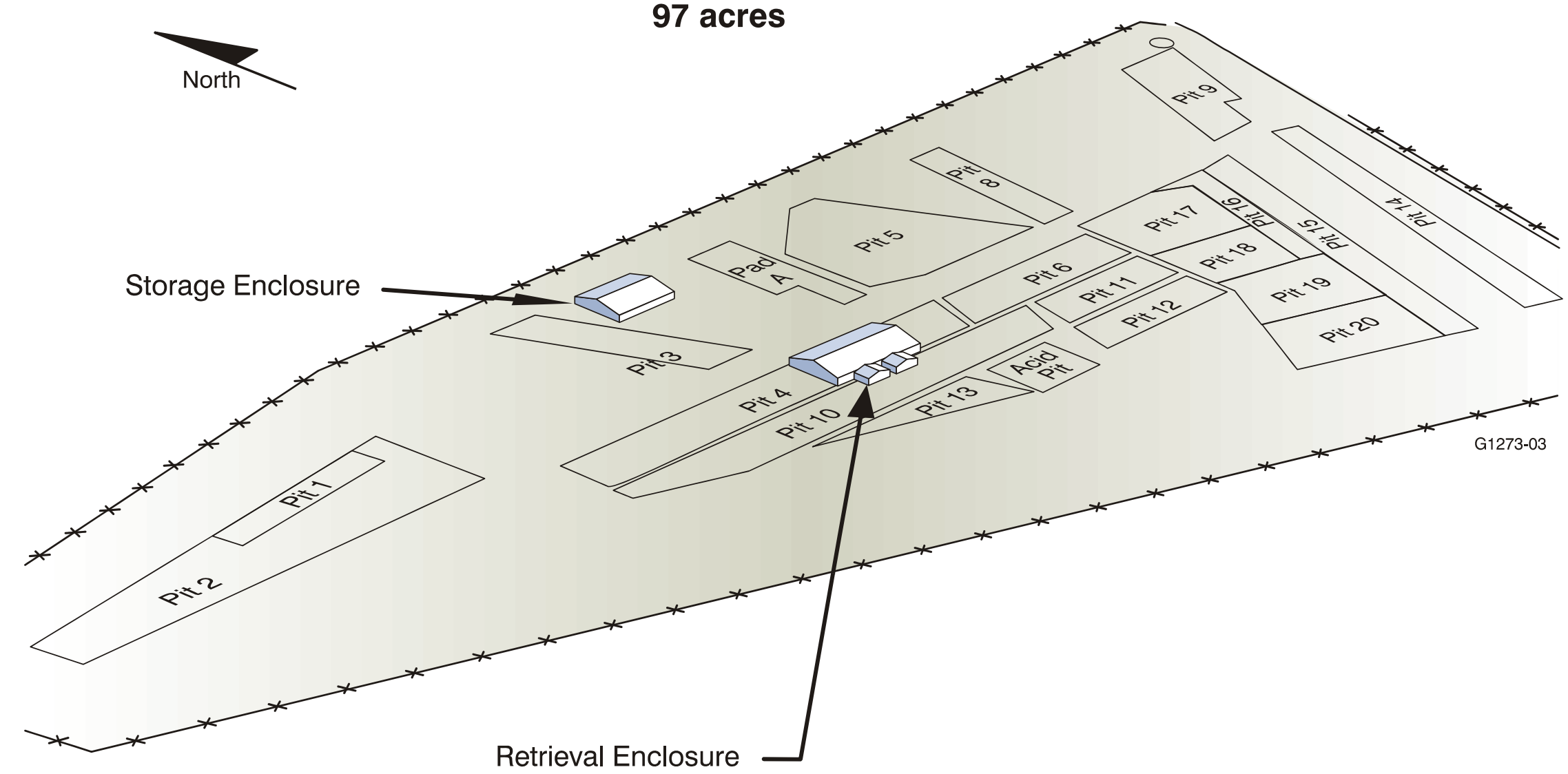

97 acres

Figure 2. Pit 4 and the Retrieval Enclosure at the Subsurface Disposal Area. 


\subsubsection{Project Objectives}

The ARP implements a NTCRA under CERCLA Section 104 (42 USC § 9601 et seq., 1980). The removal alternative selected through the evaluation presented in the EE/CA will perform a targeted retrieval of certain RFP waste streams that are highly contaminated with TRU radionuclides, VOCs, and depleted uranium. To achieve this objective, the NTCRA primarily will focus on removal of the following RFP waste streams: Series 741 and 743 sludges, graphite, filters, and depleted uranium roaster oxide waste.

During the process of excavation, other waste will be revealed that is not within these targeted waste (TW) streams. This nontargeted waste (NTW) also may be removed on a case-by-case basis if the DOE and DEQ Federal Facility Agreement and Consent Order project managers and the EPA Waste Area Group (WAG) 7 remedial project manager agree that retrieval is warranted. This decision will be made if the information concerning the NTW that is available from visual inspection (such as package labeling or distinctive packaging) identifies the NTW as being of a nature that:

- $\quad$ Poses a potential risk of contamination to the underlying aquifer if left in place

- $\quad$ The potential risk is sufficient to warrant removal at that time rather than leaving it to be addressed by the OU 7-13/14 final remedial action for WAG 7

- $\quad$ The waste can be safely managed using the personnel, facilities, and equipment readily available on the INL Site for retrieval of the waste.

\subsubsection{Background of Pit 4 within the Subsurface Disposal Area}

The SDA is a radioactive waste landfill with shallow subsurface disposal units consisting of pits, trenches, and soil vaults. The buried RFP TRU waste is located primarily in disposal Pits 1-6, Pits 9-12, and Trenches 1-10. Trenches 11-15 also may contain RFP waste. Contaminants in the SDA, including chemicals, contact- and remote-handled fission and activation products, and TRU radionuclides, are discussed in greater detail in Section 1.1.3.

Pit 4 was open to receive waste from January 1963 through September 1967. Based on the disposal practices at the time, containerized waste, primarily from RFP, was initially stacked in the pit. This practice was later changed, and containers were dumped into the pits, rather than stacked to reduce labor costs and personnel exposures. Based on retrieval information resulting from initial retrieval activities, a portion of the waste in the west end of the original retrieval area is stacked. Inventory information indicates that the waste in the remainder of the pit was most likely dumped rather than stacked. Additional waste from INL Site waste generators and some waste from off-INL Site generators also were disposed of in the pit.

The disposal process in the 1960s involved excavating an area in the SDA with tractor-drawn scrapers to the outcroppings of the underlying basalt, followed by backfilling and leveling the newly

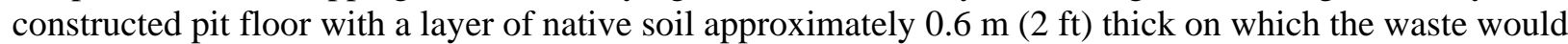
be placed. Waste in drums; cardboard, wood, and metal boxes; and other containers were disposed of.

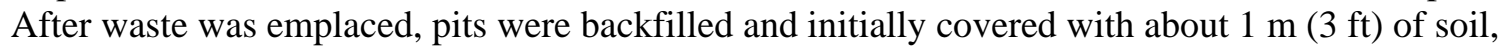
commonly referred to as overburden soil. The estimated overburden thickness in Pit 4 ranges from 1.2 to $2.1 \mathrm{~m} \mathrm{(4} \mathrm{to} 7 \mathrm{ft}$ ). The additional soil thickness resulted from maintenance activities that added soil cover to the SDA in the 1970s and 1980s (Holdren et al. 2002; INEL 1985). After approximately 40 years of burial, the original disposal containers, including the carbon steel drums, were expected to be significantly degraded similar to the drums removed in early 2004 as part of the Glovebox Excavator 
Method Project activities. However, initial retrieval experience has shown that the drums in the designated retrieval area are in significantly better condition than those retrieved from Pit 9 in 2004. Many drums are relatively intact, especially those associated with the stacked waste. Pictures of retrieved waste during the Glovebox Excavator Method Project can be viewed in Section 3 of the Excavation Plan and Sequential Process Narrative for the Accelerated Retrieval Project for a Described Area within Pit 4, ICP/EXT-04-00283 (Excavation Plan) (Preussner et al. 2004).

Pit 4, shown in Figure 2, is located in the approximate center of the SDA and shares a common eastern boundary with Pit 6 . Pit 4 has a surface area of $9,948.2 \mathrm{~m}^{2}\left(107,082 \mathrm{ft}^{2}\right)$. The total volume of Pit 4 is estimated at $45,307 \mathrm{~m}^{3}\left(1,600,000 \mathrm{ft}^{3}\right)$ (Holdren et al. 2002). The excavation area comprises approximately $21 \%$ of the overall area of Pit 4 with approximate dimensions of $38.4 \times 74.1 \mathrm{~m}$ $(126 \times 243 \mathrm{ft})$, hereinafter referred to as the Pit 4 retrieval area. As discussed in this section, the Pit 4 retrieval area was selected because it contains high concentrations of TRU waste and also contains significant volumes of other TW forms, including VOCs and depleted uranium. The approximate 0.2-ha (1/2-acre) size was selected, based on disposal records of the distribution of waste in the pit and other engineering factors (e.g., economies of scale associated with retrieval).

\subsubsection{Estimated Waste Inventory in the Designated Retrieval Area of Pit 4}

The OU 7-13/14 Project has developed extensive information defining the waste inventories disposed of in the pits, trenches, and soil vault rows in the SDA. Disposal records and corresponding trailer load list information from RFP are the ultimate source for the available information for the disposal locations and waste type designations. The OU 7-13/14 Project has developed a number of databases and supporting geographical information system applications to document waste inventory type, quantity, and location information. Based on this information, an engineering design file (EDF) has been developed, "Waste Inventory of the Described Area within Pit 4 for the Accelerated Retrieval Project within the Radioactive Waste Management Complex" (EDF-4478). The EDF summarizes the information on the volumes and types of waste that were disposed of in the Pit 4 retrieval area. Table 1 provides a summary of information contained in the EDF, including information describing the major waste streams located in the designated retrieval area from RFP.

The RFP waste forms contain various radiological and nonradiological contaminants. The waste shipped to Pit 4 from RFP included plutonium, americium, neptunium, and uranium isotopes. Plutonium isotopes included Pu-238, Pu-239, Pu-240, Pu-241, and Pu-242. Uranium isotopes (i.e., U-234, U-235, U-236, and U-238) were shipped to RWMC in the form of depleted uranium oxides. Also included in the waste shipments were Am-241 and trace quantities of Np-237. The isotopes Am-241 and Np-237 are daughter products resulting from the radioactive decay of $\mathrm{Pu}-241$. In addition to the Am-241 produced by the decay of the Pu-241, Am-241 removed from plutonium during processing at RFP also was disposed of in Pit 4. This extra Am-241 is a significant contributor to the total radioactivity located in Pit 4. A number of radionuclides (e.g., Co-60, Sr-90, Y-90, Ba-137, and Cs-137), primarily from INL Site waste generators, also are expected to be encountered in the Pit 4 retrieval area. The non-RFP waste streams include radioactively contaminated sewage sludge and a number of combustible and noncombustible debris waste forms.

Waste management activities will be based on information from the various inventory documents identified in this document and additional AK documentation being prepared to support the NTCRA. In addition, analytical data collected during project activities will be used to determine appropriate management of primary waste streams. 
Table 1. Rocky Flats Plant waste content in the designated retrieval area of Pit 4 within the Subsurface Disposal Area.

\begin{tabular}{|c|c|c|c|c|c|}
\hline Waste Stream & $\begin{array}{l}\text { Item } \\
\text { Description } \\
\text { Code }\end{array}$ & Summary Characteristics & Packaging & $\begin{array}{c}\text { Estimated } \\
\text { Waste Volume } \\
\left(\mathrm{ft}^{3}\right)\end{array}$ & $\begin{array}{l}\text { Targeted Waste/ } \\
\text { Nontargeted } \\
\text { Waste }\end{array}$ \\
\hline $\begin{array}{l}\text { Series } 741 \text { first-stage } \\
\text { sludge }\end{array}$ & 001 & $\begin{array}{l}\text { Salt precipitate containing plutonium and } \\
\text { americium oxides, depleted uranium, metal } \\
\text { oxides, and organic constituents. }\end{array}$ & $\begin{array}{l}18.1 \text { to } 22.7 \mathrm{~kg} \text { ( } 40 \text { to } 50 \mathrm{lb} \text { ) of Portland cement } \\
\text { added to top and bottom of drum to absorb any } \\
\text { free liquids. Encased in two plastic bags. }\end{array}$ & 7,317 & Targeted waste \\
\hline $\begin{array}{l}\text { Series } 742 \text { second-stage } \\
\text { sludge }\end{array}$ & 002 & $\begin{array}{l}\text { Salt precipitate containing plutonium and } \\
\text { americium oxides, metal oxides, and organic } \\
\text { constituents. }\end{array}$ & $\begin{array}{l}18.1 \text { to } 22.7 \mathrm{~kg} \text { ( } 40 \text { to } 50 \mathrm{lb} \text { ) of Portland cement } \\
\text { added in layers to absorb any free liquids. } \\
\text { Encased in two plastic bags. }\end{array}$ & 6,082 & $\begin{array}{l}\text { Nontargeted } \\
\text { waste }\end{array}$ \\
\hline $\begin{array}{l}\text { Series } 743 \text { sludge } \\
\text { organic setups }\end{array}$ & 003 & $\begin{array}{l}\text { Organic liquid waste solidified using calcium } \\
\text { silicate (pastelike or greaselike). }\end{array}$ & $\begin{array}{l}113.6 \mathrm{~L} \text { ( } 30 \text { gal) of organic waste mixed with } \\
45.4 \mathrm{~kg}(100 \mathrm{lb}) \text { calcium silicate. Small } \\
\text { quantities ( } 4.5 \text { to } 9.1 \mathrm{~kg} \text { [10 to } 20 \mathrm{lb} \text { ]) of } \\
\text { Oil-Dri added to top and bottom, if necessary. } \\
\text { Encased in two plastic bags. }\end{array}$ & 5,846 & Targeted waste \\
\hline $\begin{array}{l}\text { Series } 744 \text { sludge } \\
\text { special setups }\end{array}$ & 004 & $\begin{array}{l}\text { Complexing chemicals (liquids), including } \\
\text { Versenes, organic acids, and alcohols } \\
\text { solidified with cement. }\end{array}$ & $\begin{array}{l}86.2 \mathrm{~kg}(190 \mathrm{lb}) \text { of Portland cement and } \\
22.7 \mathrm{~kg}(50 \mathrm{lb}) \text { of magnesia cement in drum } \\
\text { followed by the addition of } 99.9 \mathrm{~L}(26.4 \mathrm{gal}) \text { of } \\
\text { liquid waste. Additional cement added to the } \\
\text { top and bottom. Encased in two plastic bags. }\end{array}$ & 853 & $\begin{array}{l}\text { Nontargeted } \\
\text { waste }\end{array}$ \\
\hline $\begin{array}{l}\text { Combustible, } \\
\text { noncombustible, and } \\
\text { mixed debris }\end{array}$ & Various & $\begin{array}{l}\text { Solid radioactively contaminated combustible } \\
\text { debris items, such as paper, rags, cardboard, } \\
\text { and wood. Noncombustible debris varies } \\
\text { widely, including pipe, empty drums, glass, } \\
\text { and sand. Some waste is contaminated with } \\
\text { beryllium metal. }\end{array}$ & $\begin{array}{l}\text { Varies by process line generating the waste. } \\
\text { Waste may have been wrapped in plastic or } \\
\text { placed directly into the waste container. }\end{array}$ & 74,959 & $\begin{array}{l}\text { Nontargeted } \\
\text { waste }\end{array}$ \\
\hline Roaster oxide waste & Unassigned & $\begin{array}{l}\text { Incinerated depleted uranium. Primary } \\
\text { chemical form is uranium oxide, with some } \\
\text { metal possible. }\end{array}$ & $\begin{array}{l}\text { Packaged in metal drums with inner plastic bag } \\
\text { packaging. }\end{array}$ & 878 & Targeted waste \\
\hline Graphite & $\begin{array}{l}300,301 \\
310,311\end{array}$ & $\begin{array}{l}\text { Graphite mold pieces after excess plutonium } \\
\text { removal. Molds are broken into large pieces } \\
\text { before packaging. Graphite fines } \\
\text { (e.g., scarfings) packaged in small bottles. }\end{array}$ & $\begin{array}{l}\text { Drums lined with polyethylene bags and, most } \\
\text { likely, a cardboard liner. Bottles of graphite } \\
\text { fines were individually wrapped in plastic bags. }\end{array}$ & 1,505 & Targeted waste \\
\hline Filters & 490 & $\begin{array}{l}\text { Discarded high-efficiency particulate air } \\
\text { filters contaminated with radionuclides from } \\
\text { the Rocky Flats Plant, such as plutonium and } \\
\text { americium. }\end{array}$ & $\begin{array}{l}\text { Packaged in cardboard cartons and boxes } \\
\text { depending on the timeframe of disposal. }\end{array}$ & 13,047 & Targeted waste \\
\hline
\end{tabular}


The TRU radionuclides in Pit 4 are believed to be primarily contained in the drummed sludge and other RFP waste (e.g., graphite). General waste definitions are provided in Figure 3 for purposes of clarification. The general waste types presented include both expected retrieved waste types and waste types that will result from construction or operations support activities (e.g., secondary waste).

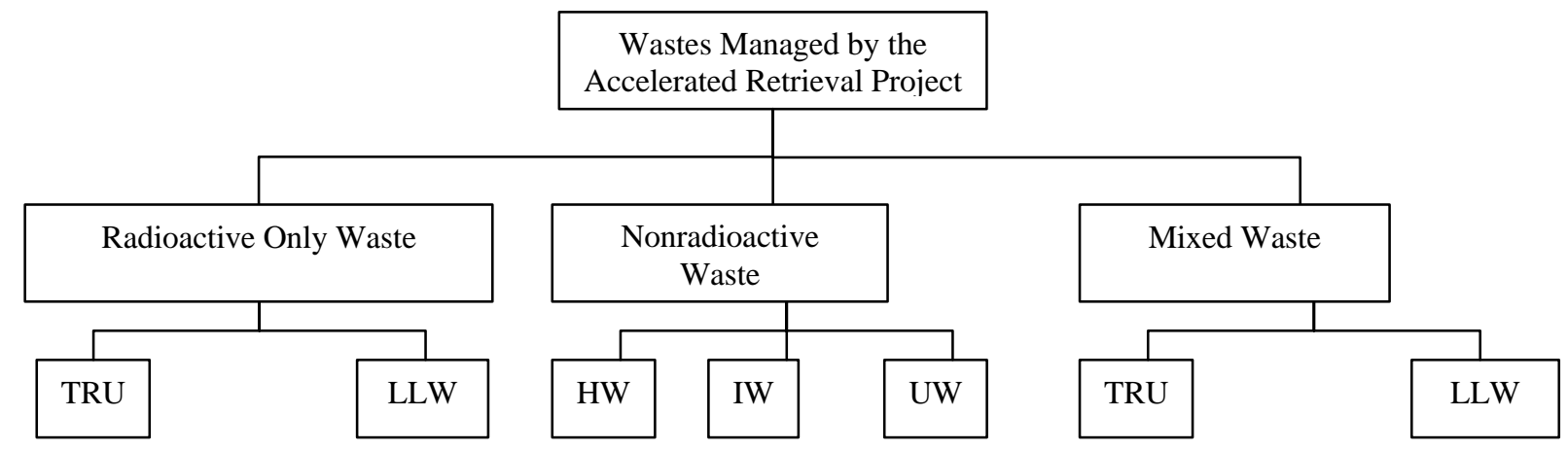

HW Hazardous waste, as defined by 40 CFR 260.10, means a hazardous waste as defined at 40 CFR 261.3.

IW Industrial waste means solid waste generated by industrial processes and manufacturing; industrial waste is not radioactive, hazardous, or mixed waste (40 CFR 243.101).

LLW Low-level waste is waste that is not high-level radioactive waste, spent nuclear fuel, transuranic waste, by-product material (as defined in Section 11e[2] of the “Atomic Energy Act of 1954” [42 USC § 2011-2259, 1954]), or naturally occurring radioactive material (DOE O 435.1).

Mixed waste Mixed waste is waste that is radiologically contaminated as defined by the Atomic Energy Act and is Hazardous Waste Management Act ( HWMA)/Resource Conservation and Recovery Act (RCRA)-regulated as defined by the Idaho Administrative Procedures Act (IDAPA) 58.01.05.005 (40 CFR 261). Most waste managed at the Accelerated Retrieval Project will be classified as mixed waste.

Nonradioactive Nonradioactive waste only applies to secondary waste and may be hazardous (i.e., HWMA/RCRA-regulated) or nonhazardous

waste Nonradioactive waste is expected to be in limited quantities and may include industrial waste and universal waste.

Radioactive

only waste

Radioactive only waste is waste that is not HWMA/RCRA-regulated as defined by the IDAPA 58.01.05.005 (40 CFR 261). If any radioactive only waste is managed at the Accelerated Retrieval Project, it is expected to be secondary waste from such activities as drum loading.

TRU

Transuranic waste is waste without regard to source or form that is contaminated with alpha-emitting transuranic radionuclides (atomic number greater than 92) with half-lives greater than 20 years and concentrations greater than $100 \mathrm{nCi} / \mathrm{g}$ at the time of assay. The primary radionuclides associated with the Subsurface Disposal Area Rocky Flats Plant transuranic waste are Pu-238, Pu-239, Pu-240, Pu-242, and Am-241.

UW Universal waste, as defined at 40 CFR 260.10, means any of the hazardous waste that is managed under the universal waste requirements of 40 CFR 273. Examples include batteries, pesticides, thermostats, and lamps.

Figure 3. General waste types.

In the SDA, a number of nonradioactive hazardous materials are present in trace amounts, of which neither the presence nor location can be verified and of which the exact quantities are unknown. These materials include picric acid, at least two 25-lb packs of sodium or potassium cyanide, lithium oxide from RFP battery waste, nitrobenzene, and polychlorinated biphenyls (PCBs) (Einerson and Thomas 1999).

Nitrocellulose is a fire and explosion hazard. An analysis has been performed on the likelihood of explosive quantities of nitrocellulose present in the SDA and the likelihood of nitrocellulose formation in the SDA. This analysis concluded that the likelihood of a nitrocellulose explosion or the formation of nitrocellulose in the SDA is highly improbable, as described in SAR-215 (2004).

\subsection{Accelerated Retrieval Project Overview}

This section provides a description of ARP-related facilities and activities. The ARP construction activities include site development and utilities work, Retrieval Enclosure (RE) and airlock installation, 
and Storage Enclosure (i.e., WMF-698) installation. The operational support facilities will be installed during the construction phase as determined appropriate by project and construction management.

\subsubsection{Accelerated Retrieval Project Facilities}

The ARP uses an RE with airlocks, WMF-698, and other support facilities. These facilities are described in more detail in the following sections.

The site development work includes the removal of overburden in the area of the RE. The overburden soil is removed and staged in a designated area of the SDA for later possible return to the pit or other use within the SDA or other appropriate off-RWMC disposal. The site utilities, building pads, power, communications lines, and other support utilities have been installed.

1.2.1.1 Accelerated Retrieval Project Retrieval Enclosure. The RE, depicted in Figure 4, is a temporary, relocatable structure that houses excavation, excavated NTW staging, and personnel and equipment ingress and egress activities. The RE provides weather protection to allow for year-round operations for ARP activities. The RE is a commercially available fabric-tensioned structure, approximately $51.8 \mathrm{~m}$ (170 ft) wide by $87.8 \mathrm{~m}$ (288 ft) long with a 6.1-m minimum (20-ft minimum) interior clearance at the eaves. Two attached structures, $21.3 \times 15.2-\mathrm{m}(70 \times 50-\mathrm{ft})$ in size, house the airlock operations that include excavator and telehandler support capabilities and waste/soil examination, packaging, and sampling systems. The RE has sufficient space and interior height to house excavator operations and waste-conveyance activities. The RE and adjoining airlock structures were installed in the area over Pit 4 where the overburden soil was previously removed.

Ventilation is provided by a high-efficiency particulate air (HEPA)-filtered ventilation system. The exhaust stack is designed to minimize local worker exposure and permit proper installation of radiological emissions monitoring equipment. The ventilation system is equipped with an emissions monitoring system to sample and record possible releases of radioactive substances.

A direct-fired heating system is used to heat the RE. The direct-fired heaters minimize the potential for propane to enter the RE because of the high burn efficiency of the units. The heater is equipped with a spark-ignited intermittent pilot and a single-stage, 24-volt gas valve.

The RE is provided with electricity for auxiliary equipment, and small electrical loads as required. Because of the mobile nature of the RE, extensive use will be made of flexible cords and cables as opposed to conductors in conduit. Lighting in the RE is both fixed position and mobile to adjust to the excavation work areas. Adequate fixed lighting is positioned to permit operators to safely walk throughout the RE.

1.2.1.2 Retrieval Enclosure Airlocks. The airlock structure is constructed to abut with the RE. The airlocks provide areas for equipment maintenance, operator entry to the retrieval area and drum packaging stations, remotely observing excavation activities, and performing decontamination activities. The buffer areas also provide for personal protective equipment (PPE) changeout. The airlocks are designed to flow approximately six air changes per hour, with the airflow going from outside the airlocks, through HEPA filters mounted in the airlock structure walls, and into the RE. Electric radiant spot heaters provide localized heating, and air conditioning is provided to maintain adequate working temperatures in the airlock structure. 


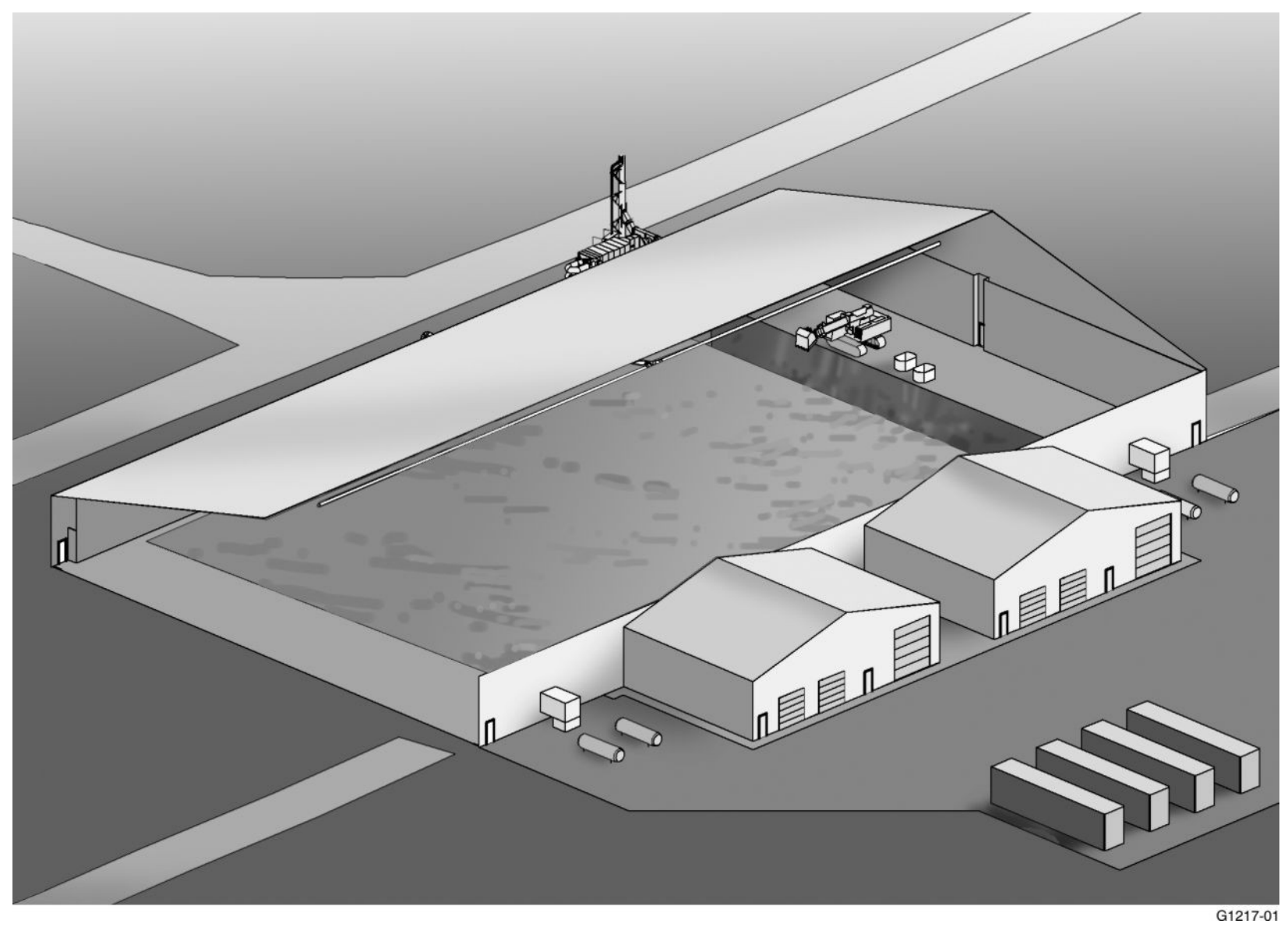

Figure 4. Depiction of the Retrieval Enclosure, showing the two attached airlocks and the retrieval area.

1.2.1.3 Storage Enclosure. Building WMF-698, depicted in Figure 5, is a temporary structure that is designed to provide indoor storage of containerized waste. Building WMF-698 is a commercially available fabric-tensioned structure, approximately $39.6 \mathrm{~m}(130 \mathrm{ft})$ wide by $48.8 \mathrm{~m}(160 \mathrm{ft})$ long, with 6.1-m minimum (20-ft minimum) interior clearance at the eaves. Building WMF-698 is constructed of a prefabricated metal frame covered with an outer polyvinyl chloride-coated polyester fabric membrane. The interior floor is constructed of reinforced concrete. Mechanical and electrical equipment supporting WMF-698 is housed external to WMF-698. Building WMF-698 is not heated but may be ventilated to minimize accumulation of VOCs, as required.

The requirements for container storage (40 Code of Federal Regulations [CFR] 264, Subpart I) are identified as applicable or relevant and appropriate requirements (ARARs) to address the storage of containerized waste within the ARP area of contamination. Although modified by a dense pack configuration, WMF-698 will satisfy the substantive Subpart I requirements for storage of hazardous waste. With the planned modified dense pack storage arrangement, WMF-698 is capable of storing approximately 12,480 drums. 


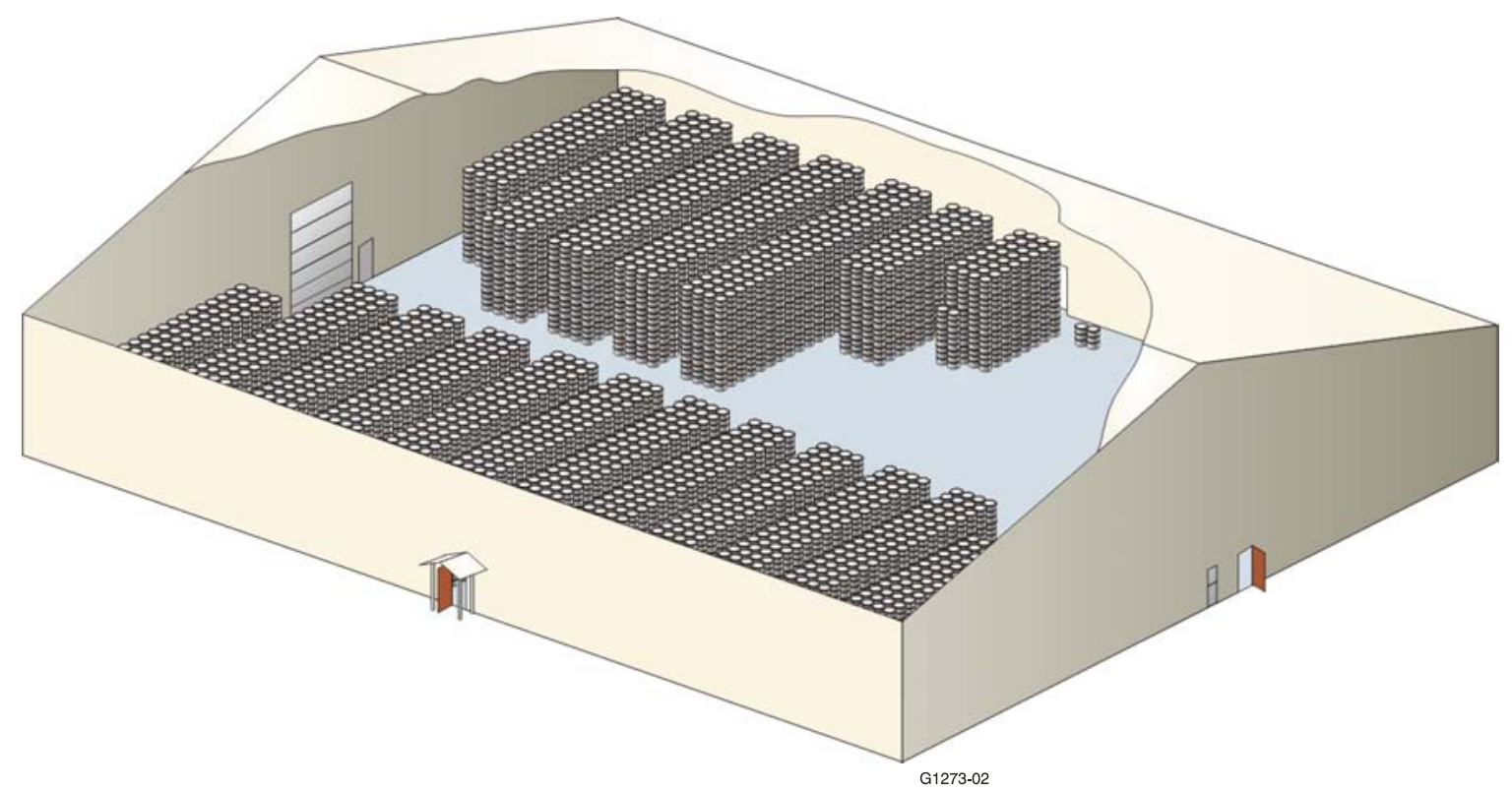

Figure 5. Depiction of WMF-698, showing an example of containers stored in the modified dense pack configuration.

In addition to WMF-698, other CERCLA storage areas are planned for use to store containerized secondary and other CERCLA waste (e.g., waste retrieved from the pit), as needed. These other areas consist of container storage areas (e.g., cargo containers, boxes, or drums) used for the accumulation of secondary waste and the temporary storage of other CERCLA waste, as needed. The areas would be registered as CERCLA waste storage areas under INL Site management control procedures (MCPs) and managed in accordance with the ARARs identified in Appendix A in addition to the requirements of applicable MCPs. An area is located near the RE (i.e., southwest of the RE). An additional area is located within the RWMC operations area north of WMF-609. Additional areas may be established onsite at RWMC as needed to support ongoing operations and provide waste management flexibility.

1.2.1.4 Operational Support Facilities. Operational support facilities include a mobile fissile material assay unit(s), breathing air unit(s), mobile sample support unit, and operations support trailers. The support facilities will be used as required to support operations, including providing a general work area, a viewing area with monitors for visual observation, PPE changeout, storage, and utility housings. The support facilities will be positioned near the RE and will be used by operations to support the activities performed onsite in the SDA and within the RE. 


\section{REMOVAL ACTION WORK ELEMENTS}

This section provides a description of the ARP removal action work elements.

The excavation process will use manned heavy equipment to retrieve targeted TRU waste from within the RE. The heavy equipment used for retrieval will be equipped with a sealed, pressurized, HEPA-filtered cab. Additionally, the operators may use self-contained breathing air or other appropriate respiratory protection.

During the construction phase of the project, overburden soil was removed to a specified depth. Upon completion of construction and turnover of the RE, readiness activities were performed in accordance with relevant DOE order requirements to ensure operational preparedness.

In summary, the removal action process involves:

- $\quad$ Removing clean overburden

- $\quad$ Erecting RE, WMF-698, and support facilities

- $\quad$ Excavating a soil layer declared as potentially contaminated soil (PCS) above the waste zone

- $\quad$ Excavating waste from the waste zone and separating TW from NTW

- $\quad$ Leaving NTW in the excavation area

- $\quad$ Visually examining and packaging TW in containers (e.g., typically 55-gal drums)

- $\quad$ Random sampling of the excavation site per agreement with Waste Isolation Pilot Plant (WIPP)

- $\quad$ Assaying and temporarily staging the drummed waste

- $\quad$ Storing waste in the CERCLA storage areas before characterization for WIPP

- $\quad$ Performing headspace gas sampling (TRU waste only)

- $\quad$ Performing gas-generation testing on drums that fail headspace gas sampling (TRU waste only)

- $\quad$ Performing limited VOC treatment of drums that fail gas-generation testing (TRU waste only)

- $\quad$ Loading and shipping the packaged TRU waste to WIPP

- $\quad$ Treating and/or disposing of remaining containers, including containers of NTW that are removed from the RE (e.g., as part of sampling activities), and TW that is later determined not eligible for WIPP disposal.

Removal of the TW streams will mitigate future potential risk by removing from the retrieval area the RFP waste streams that contain significant concentrations of the contaminants of concern in RFP waste identified in the OU 7-13/14 risk assessment (Becker et al. 1998) work that has been completed to date. Potential risk associated with the contaminants of concern not addressed through the proposed NTCRA (i.e., in other locations within the SDA) ultimately will be addressed through the selected remedial alternative to be documented in the OU 7-13/14 comprehensive record of decision (ROD). 


\subsection{Construction Activities}

The major phases planned to complete the construction work on the ARP are as follows:

- $\quad$ Site development: Site construction consisted of removing overburden soil, improving existing roads, developing a laydown area, preparing the enclosure and trailer pad, and installing temporary electrical power. Additional earthwork activities included developing permanent and temporary construction access ramps and roads to the AR site, and placing a dust-suppressing agent at designated locations.

- $\quad$ Overburden soil was removed as part of the construction activities associated with the ARP. Approximately $0.6 \mathrm{~m}$ ( $2 \mathrm{ft}$ ) of overburden soil was removed under this initial campaign. The overburden soil was piled in the SDA for future use and/or spread to meet the requirements for RWMC operations. The overburden soil piles were coated with Soiltac, a nonhazardous vinyl acrylic copolymer emulsion that binds the soil particles together to form a surface resistant to fugitive dust emissions.

- $\quad$ After the top layer of clean overburden soil was removed from the retrieval area, the exposed, graded soil was coated with Soiltac so that a durable working surface is available for the operation phase. After the graded soil was coated, the product was mixed into the soil to a depth of $10 \mathrm{~cm}$ (4 in.). When cured and compacted, a hard, relatively dust-free surface was produced that can support the operation of construction equipment. The remaining $0.6 \mathrm{~m}$ (2 ft) of overburden soil, referred to as PCS, will be removed during the first phase of remedial operations.

- $\quad$ A woven geo-textile material was placed on the new roads and structure pads before placing clean fill. Site development included installing an electrical power and communications duct to the ARP site. Asphalt paving associated with the site development was performed upon substantial completion of the RE.

- $\quad$ Structures: The major enclosure structures associated with the project are the RE and WMF-698. See Section 1 for a brief description of these two structures. Upon delivery of the government-furnished equipment, the steel framing and fabric installations were erected. To accelerate and maintain schedule, full use of resources will be used to work many areas concurrently.

- Mechanical, electrical, and supporting equipment: Installation of the supporting systems to the RE and WMF-698 involved connecting utilities and installing electric power, lighting, grounding, lightning protection, ventilation, fire alarm systems, communication systems, dust suppression on the excavator, breathing air systems, radiological monitoring equipment, and fissile monitoring systems (in the assay trailer), as required. Major mechanical and electrical equipment supporting the retrieval operations are housed outside the enclosures.

\subsection{Readiness and Startup Activities}

This section provides a description of the startup activities performed before operations.

Initiation of retrieval and waste processing activities are conducted in accordance with DOE orders. Project retrieval activities were evaluated through a management self-assessment process, followed by contractor and DOE readiness reviews. Readiness for other support functions, including drum packaging, 
assay, and waste storage, were assessed through a management self-assessment process. Retrieval startup was authorized by DOE.

\subsection{Operations}

This section provides a brief description of ARP operations.

Operating crews have been established to conduct retrieval activities to align with the ARP schedule. Operations are based on manned operations of equipment within the RE. The operational activities include retrieval of waste from the waste zone; waste sampling, examination, and packaging; and facility closure activities. The operations team will use excavation equipment and appropriate PPE to ensure worker safety.

The initial effort to retrieve waste from the excavation area began with removal of approximately $0.6 \mathrm{~cm}(2 \mathrm{ft})$ of PCS that lies directly atop the waste. Using the excavator, the heavy equipment operator removed PCS from a predetermined area, without driving the excavator directly on the waste. The PCS material is staged in a pile within the RE. Current planning indicates that the staged PCS will be used as an initial cap for the NTW to remain in the pit following removal of the TW streams.

The information on the types of waste and associated volumes that were disposed of in the Pit 4 retrieval area includes the general location within the Pit 4 retrieval area that the waste was placed. This information is available to the operators to assist with identifying waste types and potential hazards associated with the waste (see Table 1 for additional information).

Visual inspection, supplemented with field screening methods, is employed to identify and segregate TW and NTW. Existing AK enables operations, based on the appearance of the different waste types encountered during excavation, to identify TWs when unearthed.

\subsubsection{Waste Excavation}

Operators in PPE will operate a trackhoe-type excavator to retrieve material from a described area within Pit 4 into waste containers. The waste zone is expected to be 3.4 to $4.6 \mathrm{~m} \mathrm{(11} \mathrm{to} 15 \mathrm{ft}$ ) deep, and the walls will be sloped to maintain an angle of repose as needed to support safe operations. The excavator will retrieve waste zone material for subsequent processing. Waste will be segregated as TW and NTW by trained operations personnel employing visual and other methods (e.g., field screening). Once segregated, TW will be repackaged into suitable containers (e.g., drums or boxes). Field screening with radiological instrumentation will be used to identify waste associated with high-energy gamma and neutron radiation to ensure that the associated waste is managed appropriately and that potential radiation exposure of operations personnel is appropriately controlled.

Nontargeted waste will require consolidation within the RE to establish the initial excavation trench. Nontargeted waste from the initial trench will be temporarily consolidated in soft-sided boxes within the RE. Once excavation has progressed farther along the excavation path, sufficient space will be available to allow excavator transfer of NTW from the active digface portion to the opposite inactive digface without this consolidation step. Consolidated NTW then will then be relocated to the inactive digface and covered with PCS materials as part of the operations process. Excavation will not target removal of the underburden soil, although some underburden soil is expected to become commingled with targeted waste during retrieval. Limited underburden sampling will be performed as described in Section 3.6. 
In addition to the Soiltac added after removing the overburden soil, dust suppression may be used during the retrieval process as conditions warrant. This activity may include adding localized water, additional Soiltac, or other dust suppressants. Dust suppressants may be used locally from the excavating equipment, or dust suppressant applicators may be used.

As part of retrieval, TW may require exposure and/or size reduction.

Based on Glovebox Excavator Method Project experience, waste inventory records, and the time since initial disposal, little if any free liquids are expected to be encountered during retrieval. If encountered and released through the retrieval activities, it is anticipated that the uncontained free liquid will absorb into the surrounding waste and soils in a relatively short timeframe. Once absorbed, the resulting waste will be retrieved as part of normal operations. If necessary, additional soil may be combined with uncontained free liquid that does not naturally absorb during the retrieval process. Any remaining uncontained free liquids associated with TW examined in the drum packaging stations will be absorbed by operations personnel before the waste is repackaged. (Discussion of management steps for containerized free liquids is provided in Section 3.1.3.5.)

\subsubsection{Completion of Retrieval}

Once the retrieval campaign is complete, staged PCS and any remaining consolidated NTW will be used to backfill the remaining trench. Additionally, waste removed from the facility that cannot be sent to WIPP and has been treated for volatile organics potentially could be placed within the remaining open trench before backfilling. Additional treatment for returned waste may be required, pending final characterization of the waste and final hazardous waste determinations (HWDs). As discussed in Section 2.8, DOE will give preference to disposal options, such as off-INL Site treatment and disposal, that do not involve a return to the pit, and will only consider returning waste to the pit that does not present unacceptable risk to the aquifer, subject to agreement with the DEQ and EPA. In the event that the open trench volume is not completely filled with the returned PCS, NTW, or potentially returned waste, the trench volume could be filled using several methods, including:

- $\quad$ Filling the open trench volume with a retrievable grout (i.e., low compressive strength), using a hose to penetrate the enclosure

- $\quad$ Transferring additional soil material into the retrieval area.

\subsubsection{Airlock Operations}

As depicted in Figure 2, the RE has two airlocks attached. One airlock is used for maintenance, and the second airlock is used to perform waste examination, sampling, and packaging operations, as follows:

- $\quad$ Maintenance airlock. Maintenance of contaminated equipment used during the retrieval process will be performed in the maintenance airlock. This airlock will also be used to perform some decontamination.

- Waste-handling airlock. Six drum packaging stations are within the airlock. Waste is managed in the drum packaging stations in lined trays. Waste received in the waste-handling airlock are monitored for radiation levels (e.g., high gamma radiation levels) and visually examined for WIPP-prohibited items. After the visual inspection, any required samples will be collected (see Section 3.6). Based upon the results of the initial inspection, NTW may be consolidated and placed into the original excavation. 
Targeted waste is further processed at a drum packaging station similar to Figure 6. Targeted waste is visually examined by WIPP-trained personnel for liquids or other WIPP-prohibited items. Any liquids are absorbed, using soil or other suitable absorbents, and any WIPP-prohibited items are removed from the tray. A visual examination record is generated, including waste contents, estimated volumes, and weights. Remnants of the original drums may be returned to the pit following removal of targeted waste. Waste Isolation Pilot Plant-related examination and other repackaging and characterization activities alternatively may be performed by personnel located within the RE.

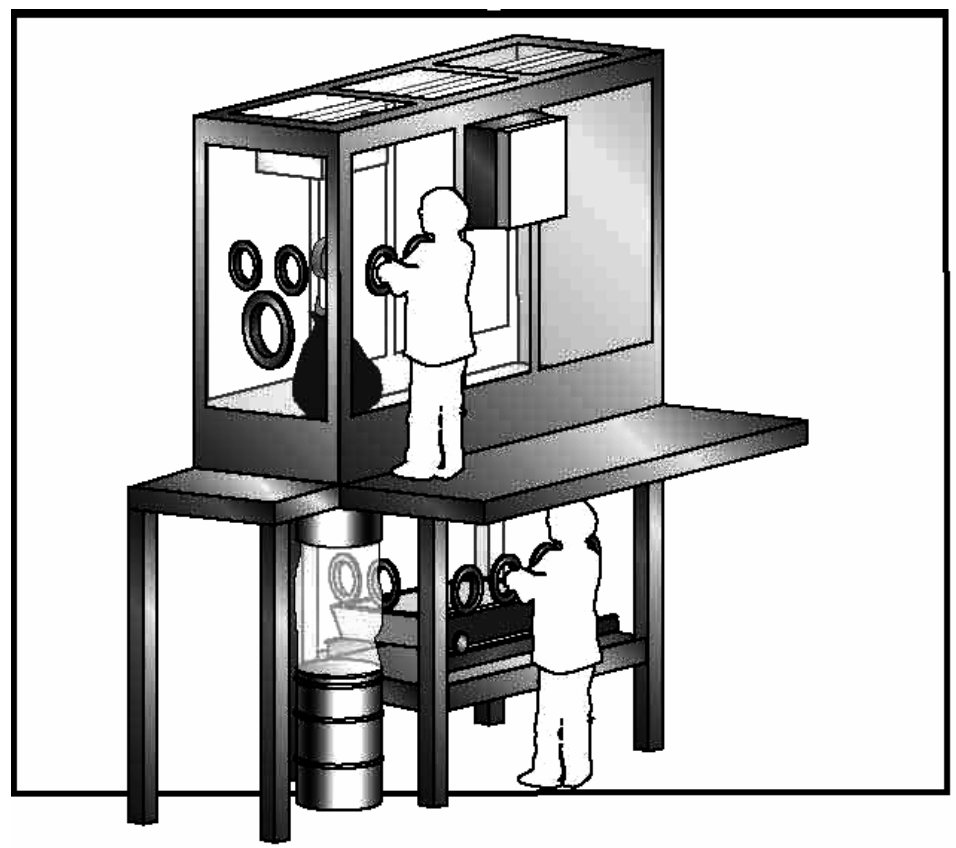

Figure 6. Artist rendition of typical drum packaging station (safety features, such as the safety railing, are not depicted).

The tray liner containing the TW is lifted, formed into a bag, placed into a bar-coded 55-gal drum, and sealed. The drum is weighed, and a vented lid is placed onto the drum. The closed drum is then decontaminated (as required) and transferred to the assay trailer.

\subsubsection{Container Storage}

Once retrieved waste is placed in new containers, the containers undergo screening assay to ensure fissile gram equivalent (FGE) limits are met for maintaining criticality safety. Any drum with greater than $380 \mathrm{~g}$ FGE is identified and transferred to special-case storage (i.e., criticality control area) and/or transferred to the drum packaging stations for repackaging into multiple containers. Other containers are temporarily staged near the assay units before being transferred to interim storage in WMF-698, which is the primary storage location for ARP waste streams. Generated drums will be transferred to the Advanced Mixed Waste Treatment Project for WIPP-related characterization. Characterization at the Advanced Mixed Waste Treatment Project will consist of assaying for TRU content, headspace gas sample analysis, and gas generation testing, if required. See Section 2.5 for additional information on WIPP shipment activities. 


\subsection{Interim Storage}

Building WMF-698, depicted in Figures 2 and 5, is a temporary structure that provides the primary indoor storage and staging of packaged waste. See Section 1 for a description of WMF-698. See Appendix A for information addressing WMF-698 operations, the related requirements, and a description of the actions taken to meet those requirements. In addition to WMF-698, other CERCLA storage areas will be established as necessary to support onsite waste management.

Retrieved waste streams may be stored alternatively within the Resource Conservation and Recovery Act (RCRA)-permitted storage facilities that are controlled and managed by the Advanced Mixed Waste Treatment Project (i.e., WMF-628 and WMF-610) and located within the RWMC Transuranic Storage Area. The RCRA permit was previously modified to allow storage of CERCLA waste in association with performing the Glovebox Excavator Method Project. Storage of ARP waste within WMF-628 or WMF-610, which are controlled by the Advanced Mixed Waste Treatment Project, will require compliance with the requirements of the Hazardous Waste Management Act (HWMA)/RCRA Permit for RWMC (i.e., Volume 5). The waste acceptance criteria (WAC) for storage of ARP retrieved waste within WMF-698 are in Appendix B.

\subsection{Waste Isolation Pilot Plant Interface Activities}

The removal action will establish process details for certification and transfer of formerly buried TRU waste to WIPP. The newly packaged waste will be evaluated for potential transfer to WIPP. Payload containers (e.g., individual drums, standard waste boxes, and 10-drum overpacks) will be assembled for transfer to WIPP in TRU package containers (TRUPACT)-II or HALF-PACT containers. Payload containers that are certified to meet the WIPP WAC will be transported to WIPP for final disposition.

The Advanced Mixed Waste Treatment Project will provide TRU waste characterization, certification, transportation, and final disposition of retrieved TRU waste. The WIPP and Idaho Cleanup Project (ICP) will work in collaboration to comply with applicable regulations to safely disposition TRU waste. Sampling and analysis conducted for chemical characterization is described in Section 3.6.

\subsubsection{Transuranic Waste Disposition}

The ARP TRU waste management approach for achieving disposition of retrieved TRU waste includes the development of baseline information supporting planning and future disposition activities, implementing visual examination and sampling under the WIPP-approved Central Characterization Project (CCP), and addressing future deployment of CCP characterization capabilities. The philosophy for achieving disposition of retrieved buried TRU waste is based on:

- $\quad$ Minimizing the level of infrastructure created or required at the INL Site for waste certification by WIPP

- $\quad$ Maximizing use of the national WIPP CCP capabilities and resources to perform characterization, certification, and transportation functions to achieve disposal of retrieved buried TRU waste.

The envisioned approach for achieving disposition of retrieved TRU waste was detailed in the original revision of this plan. To date, the major required supporting activities for disposition of the ARP waste at WIPP have been completed. These support activities include completing and approving project AK documentation, deploying and installing CCP facilities at RWMC, and completing the required certification audit process. 


\subsection{Interim Closure}

The ARP will implement interim closure steps, including covering the disturbed portion of the pit

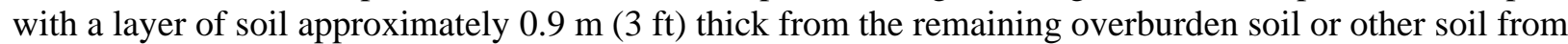
the INL Site. The cover layer will be compacted and graded consistent with the overall SDA grading and drainage plan. Final closure of the Pit 4 retrieval area will not occur as part of the NTCRA, but will occur for the overall SDA closure as specified in the pending OU 7-13/14 ROD. This final closure of the SDA is assumed to include an engineered, multilayered soil cover that will encompass Pit 4.

\subsection{Treatment}

The waste that does not pass WIPP-related acceptance criteria (e.g., gas-generation testing) may require treatment for constituents such as VOCs. As stated in the EE/CA, a thermal desorption process for treatment of VOCs is being evaluated to support this function. Decisions regarding specific treatment technology will be made in conjunction with DOE-ID, DEQ, EPA, and other stakeholders. A Remedial Design Fact Sheet will be used to brief the public.

Treatment options will be identified if waste has been retrieved that is unacceptable for shipment to WIPP or another waste-receiving facility. Final selection of a treatment method will be based on waste characterization information, regulatory requirements, stakeholder input, and technological feasibility. Details of the potential VOC or other treatment processes will be fully developed during the design process for the system. Treatment system design and other supporting documentation, such as any required risk assessment and test planning documentation, will be developed and submitted to the regulatory agencies in support of treatment system construction and implementation. The currently identified ARARs associated with treatment are identified in Appendix A.

\subsection{Alternative Disposal}

Waste profiles will be developed for retrieved waste that cannot be shipped to WIPP. This waste will remain in storage pending an acceptance determination from alternate treatment and disposal facilities. The DOE will give preference to disposal options, such as off-INL Site treatment and disposal, that do not involve a return to the pit, and only will consider returning waste to the pit that does not present unacceptable risk to the aquifer, subject to agreement with the DEQ and EPA. In the event that retrieved waste is identified to contain PCBs greater than or equal to $50 \mathrm{ppm}$, the waste will not be eligible for return to the pit without supportive risk-based disposal approval or other compliant treatment.

\subsection{Demobilization and Decontamination}

Planning for facility demobilization and decontamination activities is in preliminary development as of the issuance of this document. Facility structures and equipment will be assessed for demobilization and reuse. Specific planning and options for reuse will depend upon final facility radiological conditions. 


\section{REGULATORY COMPLIANCE}

This section provides information addressing ARP waste management strategies and a list of the ARP ARARs.

\subsection{Waste Management}

Pit 4 retrieval activities involve the retrieval and characterization of a variety of waste forms that result in packaged containers of retrieved waste requiring interim storage. Interim storage will occur in WMF-698 and other CERCLA storage areas located in the SDA while awaiting assay results, completion of HWDs, and other required documentation. The majority of the retrieved waste is expected to meet the WIPP WAC for disposal.

The ARP comprises distinct phases: construction, overburden removal, Pit 4 waste retrieval and associated operations, facility shutdown, facility layup (potentially), and finally, deactivation, decontamination, and decommissioning (DD\&D) of the facility structures and equipment. Accompanying the retrieval of the Pit 4 waste is the generation of various secondary waste streams.

Various waste types, as described in Figure 3, are associated with the Pit 4 retrieval process. Waste will be produced from the following two waste sources:

- $\quad$ Secondary waste - A generic category for waste generated from support activities related to retrieving, processing, sampling, and packaging ARP waste. Examples of secondary waste include waste from decontamination activities, PPE from maintenance and operations, used equipment, and sampling materials. Secondary waste is generated during all project phases.

- $\quad$ Pit 4 retrieved waste-Targeted waste that was originally disposed of in the Pit 4 retrieval area.

Storage in WMF-698 will include provisions for waste in containers on a concrete pad and in a temporary building. Analytical results and associated HWDs performed for these waste streams will determine the final disposal location. It is anticipated that newly generated and retrieved waste streams will require management as one or more of the waste types listed in Figure 3. As noted previously, storage of retrieved waste streams may be performed alternatively within the RCRA-permitted storage areas located within the RWMC Transuranic Storage Area.

Depending on the disposition pathway, waste will be defined and characterized in accordance with WAC from the appropriate facility. The WAC provided in Appendix B will apply to WMF-698. Storage of ARP waste in WMF-628 or WMF-610 will be subject to the requirements of the RCRA/HWMA permit requirements and any associated WAC controlled by the Advanced Mixed Waste Treatment Project. As noted, the Idaho CERCLA Disposal Facility (ICDF) WAC (DOE-ID 2005b) may apply to certain secondary waste streams if sent to ICDF for disposal. In addition, applicable INL Site MCPs and federal and state regulations for identifying waste will be implemented. A more detailed discussion about waste identification is included in succeeding sections.

\subsubsection{Waste Management Assumptions and Regulatory Considerations}

All waste streams identified in this document will be managed in accordance with the ARARs outlined in Appendix A when managed in CERCLA storage areas. Administrative requirements, such as timeframes or reporting requirements, do not apply to the waste remaining in CERCLA storage, but may be implemented if required by internal INL Site procedures or may be adopted as best management practices. Waste shipped to a treatment, storage, and disposal facility outside the INL Site will comply 
with the offsite rule 40 CFR 300.440, "Procedures for Planning and Implementing Off-Site Response Actions.”

\subsubsection{Hazardous Waste Determination}

To ensure appropriate management of waste generated during project activities, an HWD conducted in accordance with 40 CFR 262.11, “Criteria for Listing Hazardous Waste,” will be performed for each newly generated waste stream.

Concurrent with the preparation of the original version of this RAP, efforts were ongoing to complete the AK documentation associated with the waste buried in the designated retrieval area. Since that time, the baseline AK documentation has been completed. The AK documentation and associated references provide detailed information relating to facility histories and process operations. The AK information is obtained from numerous sources, including facility safety basis documentation, facility procedures, generator and storage facility waste records, and interviews with cognizant personnel. Revision 1 of the AK summary report, titled Central Characterization Project Acceptable Knowledge Summary Report for A Described Area in Pit 4 at the Idaho National Engineering and Environmental Laboratory (Wastren Energy Services 2004), was used as the primary source of preliminary HWD background information in this RAP. The following subsections describe the HWDs for various waste types expected to be encountered during retrieval based on the AK summary report. It is anticipated that the AK summary report will be revised in the future as the development of AK information progresses. The relevant information in this RAP will not be further updated to remain current with the AK documentation. The AK summary report should be used as the formal reference for AK-related information and information related to hazardous waste determinations for the ARP primary waste streams. The HWDs presented in this RAP function primarily to guide onsite CERCLA waste management planning assumptions. Subsequent to waste generation, sampling, and analysis, any or all of the waste may be reclassified. Before ultimate disposal, waste may need to be further characterized to ensure compliance with WAC for the receiving facility.

\subsubsection{Preliminary Hazardous Waste Numbers}

It is expected that the primary waste stream from the ARP activities will consist of commingled, originally disposed of waste streams. This expectation is realized because retrieval with the trackhoe-type excavator will lead to some commingling of the buried waste. In addition, a portion of the original waste containers are assumed to have lost their integrity through long-term corrosion. Because of commingling and potential cross contamination, it is assumed for planning purposes that all of the hazardous waste numbers (HWNs) from the waste streams will be combined and assigned to all of the waste, with the exception of the D001, D002, and D003 HWNs. Deviation from this approach may occur on a case-bycase basis (e.g., in particular for waste not eligible for transfer to WIPP) as may be appropriate to address site-specific and waste stream-specific circumstances.

3.1.3.1 Characteristic Hazardous Waste Numbers. A number of preliminary toxicity characteristic HWNs are identified as applying to the retrieved waste based on the AK summary report. These toxicity characteristic HWNs include the following toxicity characteristic metals and organics: D004 through D011, D022, D027, D028, D029, D030, D032, D034, D038, and D043.

The following paragraphs that deal with the characteristics of ignitability, corrosivity, and reactivity are taken directly from the AK summary report. In general, the conclusion is that the repackaged targeted waste stream should not exhibit ignitability, corrosivity, or reactivity. This conclusion will be verified as part of the final HWD evaluation, following visual inspection and final packaging. Although in some instances, the historical processes did generate chemicals or waste forms 
that in and of themselves could lead to the assignment of one of these HWNs (e.g., a liquid that is potentially corrosive), operational steps will be implemented to ensure that the final packaged targeted waste form does not exhibit characteristics that are WIPP-prohibited. Examples of these operational steps, discussed further below, include absorption of free liquids and removal of prohibited items, such as containers of free liquids. Waste management planning associated with any special-case items that are removed from the waste stream destined for WIPP is discussed in Section 3.1.3.5.

3.1.3.1.1 Ignitability-The debris materials in these waste streams do not meet the definition of ignitability as defined in 40 CFR 261.21. The materials are not liquid, ignitable compressed gases, or oxidizers, and are not capable of causing fire through friction, absorption of moisture, or spontaneous chemical change.

Any uncontainerized liquids discovered during retrieval or packaging are absorbed into the soil or other suitable absorbents. Bottles of chemicals will be removed from the waste during retrieval and packaging operations. Ignitable compressed gases (e.g., unpunctured aerosol cans or compressed gas cylinders) may be present in the waste. These items are discussed in Section 3.1.3.5.

Based on review of AK documentation, numerous oxidizers (e.g., chromates, nitrates, perchlorates, permanganate, and peroxides) have been identified in processes that generated the waste buried in Area 1. There is the possibility that bottles of chemicals, including oxidizers, were buried in the SDA. For that reason, bottles of chemicals (solids and liquids) will be removed from the waste during retrieval and packaging operations. Cellulosic (e.g., wipes) waste items may be contaminated with oxidizers; however, tests performed by Savannah River Site in 1984 to determine burning characteristics of wipes and mop heads contaminated with nitric acid and potassium permanganate indicated that these wastes are not considered oxidizers.

Depleted uranium machine turnings were thermally stabilized to an oxide (i.e., roaster oxide); however, due to incomplete oxidation of some of the turnings, combustion may be possible if unoxidized surfaces are exposed to oxygen. Other radioactively contaminated machine turnings from RFP were typically cemented. Small quantities of laboratory metals used at RFP, such as potassium and sodium, were reacted with alcohol in the laboratories. Sodium and sodium-potassium metals from ATI were encased in concrete and, therefore, do not pose a hazard. Other pyrophoric materials, such as zirconium chips from INL Site generators, were buried in the pits.

The possibility of nitrocellulose formation on unwashed acid-contaminated combustibles and plastics has been evaluated, resulting in a determination that the formation of this compound is not possible for the waste in the designated retrieval area.

Because the waste in Area 1 was buried nearly 40 years ago, and there previously have been floods from rapid snowmelt in the SDA, the waste containers may show various degrees of degradation. As a result, the potential risk for any chemical reaction is expected to be significantly reduced. Therefore, EPA HWN D001 is not assigned. The waste will be observed for any ignitability characteristics (e.g., burning, smoking, smoldering, or sparking) during retrieval and packaging operations. Further evaluation of the waste will be required if ignitability characteristics are encountered.

3.1.3.1.2 Corrosivity-The debris materials in these waste streams do not meet the definition of corrosivity as defined in 40 CFR 261.22 because the waste is not liquid. Any uncontainerized liquids discovered during retrieval or packaging are absorbed into the soil or other suitable absorbents. Bottles of chemicals will be removed from the waste during retrieval and packaging operations. There is the possibility that lead-acid batteries were buried, although the batteries would not be TW. Therefore, EPA HWN D002 is not assigned. 
3.1.3.1.3 Reactivity-The debris materials in these waste streams do not meet the definition of reactivity as defined in 40 CFR 261.23. The materials are stable and will not undergo violent chemical change. The materials will not react violently with water, form potentially explosive mixtures with water, or generate toxic gases, vapors, or fumes when mixed with water. The materials do not contain cyanides or sulfides in concentrations sufficient to generate toxic gases, vapors, or fumes. The materials are not capable of detonation or explosive reaction if subjected to a strong initiating source or if heated under confinement. The materials are not readily capable of detonation or explosive decomposition or reaction at standard temperature and pressure.

Water reactive metals (e.g., calcium, lithium, and magnesium) have been identified in several documents. Small quantities of laboratory metals were reacted with alcohol in the laboratories. Larger quantities were burned in pits at RFP.

Cyanide pellets were distributed among drums of second-stage sludge. A 1967 logbook for Series 742 sludge specifies cyanide pellets in a drum generated in August 1967. This drum will not be in Area 1 because the last date waste was buried in Area 1 is April 1967. Because earlier Series 742 sludge logbooks have not been located, it is not known if cyanide pellets were disposed of in Series 742 sludge before 1967. However, cyanide-plating operations were limited in the 1960s, and disposal of cyanide pellets would not have been a routine practice. No other specific information has been found that indicates cyanide pellets were disposed of before that time. If packages or bottles of cyanide pellets are identified in the sludge during visual examination, they will be removed from the waste streams and handled as special-case items. Cyanide solutions used in Buildings 444 and 881 were treated to destroy the cyanide.

Before 1970, ion-exchange resins may not have been denitrated (washed with water) or mixed with cement before disposal. In the past, there was some question if the resins that have dried out represent a flammable or explosive hazard. However, studies indicate that no credible mechanism exists for spontaneous detonation by degradation of a nitrate-form ion-exchange resin.

Previous studies identified the potential for shock sensitivity or violent exothermic reaction of leaded gloves exposed to nitric acid under the proper conditions. However, because the waste in Area 1 was buried nearly 40 years ago, and there have been previous floods in the SDA, the proper conditions do not exist for the gloves to be reactive.

Small quantities of explosives were used at RFP; however, they were strictly regulated and controlled and would not have been placed in drums for burial. Explosives, such as blasting caps and primacord, were used at several INL Site facilities. No information has been found that indicates how explosives from INL Site generators were managed. Explosive chemicals, such as hydrazine and picric acid, have been identified in several documents. Small quantities of picric acid were disposed of in the SDA, although the specific location cannot be verified. Before 1970, chemicals that were no longer needed were included in contaminated RFP waste for burial. Although chemical names are not specified, explosive chemicals, such as picric acid used at RFP, were burned onsite and would not have been placed in drums for burial.

Because the waste in Area 1 was buried nearly 40 years ago, and there have been previous floods in the SDA, the waste containers may show various degrees of degradation. As a result, the potential risk for any chemical reaction is expected to be significantly reduced. Therefore, EPA HWN D003 is not assigned. The waste will be observed for any unanticipated reaction during retrieval and packaging operations (e.g., smoking, smoldering, and sparking). In addition, potentially reactive materials (e.g., metal turnings and bottles containing liquid or solid materials) will be removed during waste retrieval and packaging operations. 
3.1.3.2 Listed Hazardous Waste Numbers. Based on information regarding waste generating processes, including use of solvents in cleaning and degreasing operations and use of cyanide in electroplating operations, the AK summary report indicates that F-listed HWNs will apply to the waste. The F-listed solvents identified as preliminary HWNs are F001, F002, F004, F005, F006, F007 and F009.

Numerous F003-listed solvents (i.e., acetone, methanol, and xylene) were used in the historical processes that generated the waste in Pit 4 . The F003-listed solvents are listed solely for ignitability; however, these waste streams do not exhibit the characteristic of ignitability and are, therefore, not assigned an F003 HWN. The absence of ignitable liquids will be verified during retrieval and packaging activities.

An evaluation of commercial chemical product disposal is presented in the AK summary report. Limited instances of commercial chemical product disposal were identified in the AK review. For example, documentation does identify the possible disposal of potassium or sodium cyanide pellets, disposal of a resin hardening agent (i.e., 10 to 20 gal of 4,4-methylene-bis, 2-chloroaniline), and disposal of mercury bottles. If encountered, these containerized chemicals will be removed from the targeted waste stream during repackaging and managed separately. With the exception of these examples, no other information was available to identify the specific chemicals disposed of. Without this specific knowledge, it is concluded that additional P- and U-listed HWNs cannot be assigned. Therefore, based on the evaluation and the planned repackaging steps, assignment of U- and P-listed HWNs to the retrieved waste from the designated retrieval area is not necessary. Assignment of listed waste codes to any individual containers of chemicals that require removal from the waste stream may be necessary, pending assessment of information collected to characterize the chemical following removal. Storage of these items is discussed in Section 3.1.3.5.

3.1.3.3 Pit 4 Retrieval Area Waste. As described earlier, retrieved waste is considered to consist of waste (i.e., sludges and debris) that was originally disposed of in Pit 4 and soils (i.e., interstitial and underburden). Although the term "sludge" is used for some of the waste, it is partially a misnomer. The "sludges" associated with ARP waste are expected to contain only absorbed moisture, as opposed to the common use of the term "sludge," which invokes the idea of free-standing or separable liquid. The Pit 4 retrieval area is known to contain sludges from RFP. Characterization information available about the processes that generated these sludges indicates that several listed and characteristic HWNs are potentially applicable. The TW in the Pit 4 retrieval area includes Series 741 and 743 sludge, graphite, filters, and roaster oxide waste streams. These waste streams are described in Table 1.

Interstitial soils will be separated from TW to the extent practicable. Underburden soils generally will generally in place and is not considered waste.

3.1.3.4 Toxic Substance Control Act Assumptions. Polychlorinated biphenyls have been recognized as a possible chemical constituent within the RFP TW streams, but definitive information on the presence or concentration of PCBs has not been available. The Glovebox Excavator Method Project characterization results have been analyzed for PCBs; analytical data collection was designed to characterize the average PCB concentration within the overall project waste stream retrieved. It is noted that the general waste types within the project retrieval area and the designated Pit 4 retrieval area are similar. Based on the analysis performed, the project waste $90 \%$ upper confidence limit PCB concentration is $37 \mathrm{ppm}$. Of course, this is below the PCB regulatory threshold of $50 \mathrm{ppm}$ or greater. However, analysis of the data indicated that a significant number of the samples analyzed did contain PCBs, some at elevated concentrations. Based on this, and differences in the composition of the waste streams to be generated (i.e., reduced interstitial soil quantity), the presence of PCBs in the ARP waste inventory at or above the Toxic Substances Control Act (TSCA) (15 USC § 2601 et seq., 1976) regulatory threshold cannot be ruled out without analytical verification. Consequently, a project storage assumption 
is that a portion of the waste population requiring storage exhibits PCB concentrations greater than or equal to $50 \mathrm{ppm}$.

As described in Section A-4 of the Action Memorandum for Accelerated Retrieval of a Described Area within Pit 4 (DOE-ID 2004b), a risk-based storage approval, in accordance with 40 CFR 761.61(c), has been documented for the project. On-INL Site CERCLA storage of project waste streams will be performed in accordance with the provisions of the risk-based approval documented as Appendix A to the Action Memorandum and consistent with appropriate INL Site waste MCPs. In the event that analytical data are collected that show the waste is not contaminated with PCBs at concentrations of $50 \mathrm{ppm}$ or greater, the provisions of the risk-based approval will no longer require implementation, and project waste management practices may be modified accordingly. Further, it is noted that implementation of the risk-based storage approval will not be relevant to storage of waste within WMF-628. Building WMF-628 is designed and operated to satisfy the requirements of TSCA for PCB storage.

3.1.3.5 Special-Case Waste and Prohibited Items. As discussed above, a number of items are contained in the waste that are prohibited from disposal at WIPP. These include unabsorbed liquids, compressed gases, and bottles of chemical reagents. The waste is visually examined to ensure prohibited items are not shipped to WIPP. Any liquids in TW are absorbed using suitable absorbents, and any other prohibited items are removed. A visual examination record is generated to document the absence of prohibited items in the repackaged waste.

Bottles containing free liquids will not be allowable for return to the pit without regulatory agency approval and appropriate risk-based justification. Because of the unknown nature of the bottles (i.e., AK information is generally not able to identify the specific chemicals that were disposed of), the bottles present safety and operational hazards. If identified in the drum packaging stations, the bottles will be examined, characterized to the extent possible with any identifiable information (e.g., labels), and subjected to a case-by-case management review by appropriate operations and environmental, safety, and health personnel to determine appropriate handling precautions and procedures. The INL Site MCPs that address management of unknowns may be followed for management and storage of any such chemicals that are removed from the drum packaging stations. Unknown chemicals would require storage as if incompatible with other waste or materials (i.e., separation by distance/barrier will be required to store unknowns).

Compressed gas cylinders, if identified in the drum packaging station, are not WIPP eligible, and may be returned to the original excavation. Aerosol cans may be vented in the drum packaging stations or returned to the pit.

Preliminary planning has identified two potential locations for managing these special-case items. The first option involves storage within portable storage units located within the SDA at RWMC that are registered as CERCLA storage areas. These units are designed for storage of RCRA-regulated (42 USC § 6901 et seq., 1976) waste and TSCA-regulated (15 USC § 2601 et seq., 1976) waste and include built-in secondary containment for storage of liquids. The second option involves managing the items within the RE, although the details of this option remain to be developed before retrieval operations commence. Final management planning for the special-case items will be developed on a case-by-case basis, depending upon the characterization information collected at the time of waste generation.

\subsubsection{Waste Segregation}

Construction waste streams generally will not be hazardous waste, but rather will be industrial waste (IW) (i.e., nonhazardous solid waste) and typically will not require RCRA- or TSCA-compliant storage. Some IW generated during construction (e.g., office waste) can be disposed of in cold-waste 
(i.e., nonradioactive) receptacles located on the construction site before final disposition in accordance with the INL WAC (DOE-ID 2005a). If hazardous waste is generated, it will be characterized on a case-by-case basis and evaluated for treatment and disposal.

Container storage areas and containers for collection of waste will be clearly labeled to identify waste type. When operators receive retrieved waste from the trench, they will handle and inspect the retrieved waste, during which WIPP-trained personnel also will physically characterize the retrieved waste via visual inspection. Characterization efforts for retrieved waste will be dictated by the WIPP/RCRA Field Sampling and Analysis Plan (Arbon 2005). Characterization includes a documented physical description of the retrieved waste. Once the retrieved waste has been containerized and the container sealed, the container will be weighed and assayed, then the container will be transferred to storage. The container storage location will be noted and added to the Integrated Waste Tracking System (IWTS). Additional relevant information, such as sample analyses results, will be entered in IWTS as results become available. This information, along with other relevant information entered into IWTS, will be used by the INL Site for dispositioning and transporting waste.

Based on analysis, TW intended for repackaging will not require segregation/separation due to chemical incompatibility (EDF-5307). If visual observations identify waste needing segregation/separation, then appropriate waste handling and storage procedures will be developed through consultation among operations and environmental, safety, and health personnel, based on relevant characterization information.

Waste will be separated to facilitate operations as deemed appropriate by the operations manager.

\subsubsection{Waste Minimization}

Each CERCLA remediation project is unique, with most having short durations. The concurrent development of this plan and ARP design phase is an example of how waste minimization is evaluated closely before operation to evaluate and consider options that will reduce the overall waste generation through the life cycle of the ARP.

Accelerated Retrieval Project waste minimization will be accomplished through design and planning to ensure efficient operations that will not generate unnecessary waste. As part of required prejob briefings, emphasis will be placed on waste reduction philosophies and techniques, and personnel will be encouraged to continuously attempt to improve methods for minimizing generated waste. A more complete discussion of waste minimization for environmental restoration projects is contained in U.S. Department of Energy-Idaho Operations Office, Idaho National Engineering and Environmental Laboratory Interim Pollution Prevention Plan (Janke 2000). Waste minimization practices that will be used include source reduction, recycle, reuse, disposal and treatment, best management practices, and training.

\subsubsection{Waste Stream Identification}

This section provides descriptions of the waste streams expected to be generated during ARP operations. Succeeding sections address waste packaging, labeling, storage, transportation, and potential waste disposal options. Table 1 provides a summary of the waste streams and estimated volumes of the TWs contained in the Pit 4 retrieval area. Appendix C provides a summary of the expected waste generated during the removal action and the planned disposal locations. 
3.1.6.1 Secondary Waste. Secondary waste includes:

- $\quad$ Waste generated during onsite construction of buildings and equipment

- $\quad$ Waste generated during initial removal of overburden soil

- Waste associated with characterization sampling, decontamination, and immobilization of residual contamination

- $\quad$ Waste associated with routine radiological monitoring of confinement and maintenance and inspection of equipment

- $\quad$ Waste generated during the DD\&D of building structures and processes;

- $\quad$ Waste generated from support activities (including operations and maintenance activities) related to retrieving, processing, sampling, and packaging of the Pit 4 retrieved waste.

Examples of secondary waste include waste associated with routine decontamination activities and PPE, administrative area and support service waste, used equipment and filters, and other similar waste generated during operations, maintenance, and sampling activities.

3.1.6.2 Retrieved Waste. Pit 4 retrieved waste consists of TW originally disposed of within Pit 4, including some commingled soils. It is estimated that approximately 12,000 55-gal drums of waste will be removed during the ARP. This amount includes both TW, commingled interstitial soils, along with some intermixed NTW. Table 1 lists Pit 4 waste targeted for retrieval.

The waste and contaminants located in Pit 4 retrieval area are described in Section 1 . The project area is presented in Figure 2. Records show that this area contains primarily RFP and some waste from INL Site generating facilities. Table 1 provides a summary of the waste containers and items to be encountered during Pit 4 waste retrieval.

3.1.6.3 Associated Interstitial Soils. Interstitial soils, like overburden soils, originated in the spreading areas and were placed among and atop the waste during burial. A layer of soil, designated as underburden, was placed over the basalt before burial of the waste in the pit. Little information is currently available about the chemical or radiological contamination levels within the interstitial soils and underburden. Overburden soil has not contacted the waste; therefore, no HWN will apply to the overburden soil.

\subsection{Container Management}

The following subsections describe the management of waste in containers during onsite CERCLA storage, transportation, and disposal.

\subsubsection{Packaging}

Packaging of Pit 4 retrieved waste will be in accordance with operation design details and procedures and the applicable WAC (see Appendix B). Packaging will be in compliance with MCP-1390, "Waste Generator Services Waste Management."

The INL Waste Generator Services (WGS), along with the Packaging and Transportation organization, will be consulted before waste is generated to identify specific types of containers to be 
used for the anticipated waste. Typical containers include 55-gal steel UN1A1 and UN1A2 drums, 85-gal overpack containers, wooden or metal boxes, and soft-sided bags. Boxes generally will be used for secondary waste that requires storage. Roll-off containers and cargo containers also may also be used. Additional containers may be used on a case-by-case basis.

\subsubsection{Labeling}

Containers will be labeled consistent with the WAC in Appendix B. Each container will be labeled with a barcode label generated from the IWTS database. The CERCLA waste labels will be affixed to containers. Container labels will be placed where clearly visible during storage and shipment. Drums will be labeled, at a minimum, on one side. Boxes will be labeled, at a minimum, on two sides of the container. Radiation labels will be completed and placed on each container as required by the Radiological Control Manual (PRD-183). Labels for PCBs will comply with TSCA regulations and will be applied to containers when necessary. In preparation for shipment, other information will be placed on the containers, such as applicable U.S. Department of Transportation labels, manifest number, gross weight, and the complete name and address of the shipper, as required. Soft-sided bags used in the area of the trench for consolidating waste will not require labeling if the bags are not removed from the RE. Additional label requirements, based on the receiving facility WAC, will be used as required (e.g., three labels per drum at an equal distance around the drum, approximately 120 degrees apart).

\subsubsection{Storage and Inspection}

For CERCLA storage, the waste will be stored within one of the CERCLA storage areas, including the use of cargo containers for interim storage, WMF-671 (Glovebox Excavator Method), or other established CERCLA storage areas. The CERCLA storage areas will be updated or expanded as needed. The design will include aisle space for inspection activities and container movement, as required. Structures will be constructed to prevent washout from storm water. The wastes stored will primarily consist of solid debris items, including a mixture of interstitial soils and retrieved wastes PCB-contaminated waste (if encountered); low-level waste; and TRU-contaminated waste. Inspections are conducted as described in Appendix A. A general inspection checklist is provided in Appendix D.

\subsubsection{Transportation}

The CERCLA remediation waste generated as a result of ARP activities will be transported in accordance with requirements identified in the INL WAC, appropriate U.S. Department of Transportation regulations, RCRA regulations, and company procedures (MCP-2669, “Hazardous Waste Shipping,” and MCP-2670, "Motor Carrier Operations"), as necessary. If shipment of CERCLA remediation waste is necessary during the project, WGS and the Packaging and Transportation organization personnel will be responsible for performing those activities. Industrial waste transported to the INL Landfill Complex will be transported in accordance with company procedures.

\subsubsection{Disposal}

Disposal of each type of waste stream generated during the ARP will be accomplished in accordance with all applicable requirements found in state and federal regulations.

Various inert materials will be used within the enclosure to support retrieval. These materials may be disposed of in the pit. Potential for future subsidence shall be evaluated at the time of deposition, and the location recorded. 
All waste will undergo characterization to ensure that the requirements of the WAC for the appropriate disposal facility are met before shipment to the disposal facility. In general, disposal of secondary and non-WIPP eligible waste streams will be pursued as soon as practical. Evaluation of potential off-INL Site disposal options for waste that is not WIPP eligible is being pursued by WGS personnel at this time.

\subsection{Applicable or Relevant and Appropriate Requirements}

Section 121(d) of CERCLA requires that removal actions satisfy ARARs to the extent practicable. Applicable requirements are those cleanup standards, criteria, or limitations promulgated under federal or state law that specifically address the situation at the CERCLA site. A requirement is applicable if the environmental standard shows a direct correspondence when objectively compared with the conditions at the site.

If a requirement is not legally applicable, the requirement is evaluated to determine whether it is relevant and appropriate. Relevant and appropriate requirements are those cleanup standards, standards of control, and other substantive environmental protection requirements, criteria, or limitations promulgated under federal or state law that, while not applicable, address problems or situations sufficiently similar to the circumstances of the proposed response action and are well suited to the conditions of the site. The criteria for determining the relevance and appropriateness are listed in 40 CFR 300.400(g)(2).

In accordance with EPA guidance, ARARs generally are classified into three categories: chemical-specific, location-specific, and action-specific requirements. These classification categories were developed to help identify ARARs, some of which do not fall precisely into one group or another. These categories of ARARs are defined as follows:

- Chemical-specific ARARs include those laws and requirements that regulate the release to the environment of materials possessing certain chemical or physical characteristics or containing specified chemical compounds. These requirements generally set health or risk-based concentration limits or discharge limitations for specific hazardous substances. If, in a specific situation, a chemical is subject to more than one discharge or exposure limit, the more stringent of the requirements generally should be applied.

- Location-specific ARARs are those requirements that relate to the geographical or physical position of the site, rather than the nature of the contaminants or the proposed site remedial actions. These requirements may limit the placement of remedial action and may impose additional constraints on the cleanup action. For example, location-specific ARARs may refer to activities in the vicinity of wetlands, endangered species habitat, or areas of historical or cultural significance.

- $\quad$ Action-specific ARARs are requirements that apply to specific actions that may be associated with site remediation. Action-specific ARARs often define acceptable handling, treatment, and disposal procedures for hazardous substances. These requirements are triggered by the particular remedial activities that are selected to accomplish a remedy. Examples of action-specific ARARs include requirements applicable to landfill closure, wastewater discharge, hazardous waste disposal, and emissions of air pollutants.

A requirement may not meet the definition of ARAR as described above, but still may be useful in determining whether to take action at a site or to what degree action is necessary. This can be particularly true when there are no ARARs for a site, action, or contaminant. Such requirements are called to-be-considered (TBC) criteria and are defined at 40 CFR 300.400(g)(3). Chemical-specific TBC requirements are applied in the absence of ARARs or when the existing ARAR is not sufficiently 
protective to develop cleanup levels. To-be-considered materials are guidance issued by federal or state governments that are not legally binding but that may provide useful information or recommended procedures for remedial action. Although TBCs do not have the status of ARARs, they are considered together with ARARs to establish the required level of cleanup for protection of human health and the environment. For a detailed description of the ARARs and TBCs for this RAP, see Appendix A.

\subsection{Emergency Planning}

An Emergency Plan/Contingency Plan (EP/CP), “INEEL Emergency Plan Resource Conservation and Recovery Act (RCRA) Contingency Plan” (PLN-114), has been prepared for the INL Site. The $\mathrm{EP} / \mathrm{CP}$ addresses the actions that are taken to protect human health and the environment in the event of an emergency. The emergency response section of the health and safety plan (HASP) (Gurney 2006) defines the roles and responsibilities of ARP operations personnel during an emergency. Such an emergency could be within the ARP operations area, at RWMC, or an INL sitewide emergency. The EP/CP provides information for evacuations or shelter-in-place actions, establishes an emergency response organization, and identifies the lines of communication. Once the INL plan is activated, ARP operations personnel will follow the direction and guidance communicated by the emergency coordinator. Additionally, the EP/CP directs the post-emergency recovery. This EP/CP is available to, and will be used by, the ARP. The $\mathrm{EP} / \mathrm{CP}$ covers alarms and communications equipment, emergency equipment, and fire protection equipment for RWMC. The INL Fire Department provides emergency fire fighting support and emergency medical support. The Central Facilities Area dispensary and ambulance are available for ARP personnel. Firewater is available at RWMC and consists of two approximately 250,000-gal water storage tanks. Additionally, Appendix L (per MCP-3475) of the EP/CP addresses ARP-specific items.

\subsection{Health and Safety}

Construction and operation of the ARP facilities will present physical, chemical, and radiological hazards to personnel. Identification and mitigation of these hazards are imperative to prevent injury or exposure to personnel conducting these activities. The primary objective of this section is to identify existing and anticipated hazards based on project operations and to provide controls to eliminate or mitigate these hazards.

Personnel may be exposed to industrial safety hazards or to radiological, nonradiological, and physical agents while conducting project operations. Designed engineering controls will be implemented along with work procedures, real-time monitoring of selected contaminants, and ARP-specific hazard training to further mitigate potential hazards and exposures. Formal preplanning (e.g., job walkdown, completion of the hazard profile screening checklists, and prejob briefing checklists), job safety analyses, and other work controls are written based on the hazards identified in the ARP HASP (Gurney 2006), technical procedures, STD-101, "Integrated Work Control Process,” work packages, and operational conditions. These documents specify specific operational hazard mitigation measures.

\subsubsection{Records Management}

The ICP Administrative Record and Document Control office organizes and maintains data and reports generated by field activities. The Administrative Record and Document Control office maintains a supply of all controlled documents and provides a documented system for the control and release of controlled documents, reports, and records. Copies of project plans; the project HASP (Gurney 2006); the quality program plan (PLN-852); the Quality Assurance Project Plan for Waste Area Groups 1, 2, 3, 4, 5 , 6, 7, 10 and Deactivation, Decontamination, and Decommissioning (DOE-ID 2004c); and other documents pertaining to these operations are maintained in the project file by the ICP Administrative Record and Document Control office. Controlled procedures for RWMC and the ARP will be issued, 
controlled, and maintained in accordance with "Document Management” (MCP-135) and applicable RWMC or project supplemental MCPs.

All additional project records will be maintained in accordance with applicable federal and state procedures, companywide manuals, and project-specific supplemental procedures.

\subsection{Sampling and Analysis}

This section provides a description of the sampling and analysis strategies to be used by the ARP.

\subsubsection{Sampling Requirements for Waste Isolation Pilot Plant Characterization}

The WIPP/RCRA Field Sampling and Analysis Plan (Arbon 2005) for characterization of retrieved TRU homogeneous solids and soil/gravel waste forms has been completed and approved by the DOE Carlsbad Field Office. This sampling plan will be updated to reflect the area to be retrieved.

Sampling and analysis consists of total analysis for VOCs, semivolatile organic compounds, and metals (i.e., antimony, arsenic, barium, beryllium, cadmium, chromium, lead, mercury, nickel, selenium, silver, thallium, vanadium, and zinc) as required by WIPP. Details regarding sampling objectives, sample design, sample locations, and analytical requirements may be referenced through review of the approved project sampling plan.

\subsubsection{Sampling of Nontargeted Waste Remaining in Pit 4 and Underburden}

The Data Quality Objectives for the Accelerated Retrieval Project for a Described Area within Pit 4 (McIlwain 2004) was issued to define data quality objectives (DQOs) for characterization of the NTW that will remain in the pit following retrieval and to characterize the underburden soils. The DQO document was reviewed by DEQ and EPA to ensure consensus on the proposed data collection. The original draft DQOs associated with this sampling were determined at a meeting held with DOE, DEQ, and EPA representatives on July 19, 2004. In that meeting, the DQO process was performed to identify agreed-upon objectives for characterization of the NTW remaining in Pit 4 after retrieval and characterization objectives for the underburden. Samples of the NTW remaining in Pit 4 and the underburden will be collected. The underburden and the NTW will be sampled and statistically evaluated as two separate populations. Sampling details and procedures, based on the DQO document, are presented in the Field Sampling Plan for the Accelerated Retrieval Project I (McIlwain 2006). 


\section{NON-TIME-CRITICAL REMOVAL ACTION SCHEDULE}

The design process for the ARP was initiated in December of 2003. Following design, construction, operations planning, operations implementation, and readiness assessment activities were completed in support of operations startup that occurred on January 13, 2005. Retrieval operations are currently projected to be completed in FY 2008. Once retrieval operations are completed, facility structures and equipment will be assessed for demobilization and reuse. In addition, performance of WIPP-related processing and certification activities and complete treatment or disposal of waste streams that are not WIPP eligible are fundamental elements for the proposed NTCRA and are expected to require several years to complete, although a final schedule is not available for these work elements at this time. 


\section{REFERENCES}

10 CFR 835, 2006, “Occupational Radiation Protection,” Code of Federal Regulations, Office of the Federal Register.

15 USC § 2601 et seq., 1976, “The Toxic Substances Control Act (TSCA) of 1976,” United States Code.

16 USC § 470 et seq., 2002, “National Historic Preservation Act of 1966,” United States Code.

40 CFR 61, 2006, “National Emission Standards for Hazardous Air Pollutants,” Code of Federal Regulations, Office of the Federal Register.

40 CFR 61, Subpart H, 2006, "National Emission Standards for Emissions of Radionuclides Other Than Radon from Department of Energy Facilities,” Code of Federal Regulations, Office of the Federal Register.

40 CFR 61.92, 2006, “Standard,” Code of Federal Regulations, Office of the Federal Register.

40 CFR 61.93, 2006, “Emission Monitoring and Test Procedures,” Code of Federal Regulations, Office of the Federal Register.

40 CFR 61.94, 2006, “Compliance and Reporting,” Code of Federal Regulations, Office of the Federal Register.

40 CFR 243.101, 2002, “Definitions,” Code of Federal Regulations, Office of the Federal Register.

40 CFR 260.10, 2006, “Definitions,” Code of Federal Regulations, Office of the Federal Register.

40 CFR 261, 2006, “Identification and Listing of Hazardous Waste,” Code of Federal Regulations, Office of the Federal Register.

40 CFR 261.3, 2006, “Definition of Hazardous Waste,” Code of Federal Regulations, Office of the Federal Register.

40 CFR 261.11, 2006, “Criteria for Listing Hazardous Waste,” Code of Federal Regulations, Office of the Federal Register.

40 CFR 261.21, 2006, “Characteristic of Ignitability,” Code of Federal Regulations, Office of the Federal Register.

40 CFR 261.22, 2006, “Characteristic of Corrosivity,” Code of Federal Regulations, Office of the Federal Register.

40 CFR 261.23, 2006, “Characteristic of Reactivity,” Code of Federal Regulations, Office of the Federal Register.

40 CFR 262.11, 2006, “Hazardous Waste Determination,” Code of Federal Regulations, Office of the Federal Register.

40 CFR 264, 2002, “Air Emission Standards for Process Vents,” Code of Federal Regulations, Office of the Federal Register. 
40 CFR 264, Subpart C, 2006, "Preparedness and Prevention,” Code of Federal Regulations, Office of the Federal Register.

40 CFR 264, Subpart I, 2006, “Use and Management of Containers,” Code of Federal Regulations, Office of the Federal Register.

40 CFR 264, Subpart X, 2006, “Miscellaneous Units,” Code of Federal Regulations, Office of the Federal Register.

40 CFR 264.13, 2006, “General Waste Analysis,” Code of Federal Regulations, Office of the Federal Register.

40 CFR 264.15, 2006, “General Inspection Requirements,” Code of Federal Regulations, Office of the Federal Register.

40 CFR 264.17, 2006, “General Requirements for Ignitable, Reactive, or Incompatible Wastes,” Code of Federal Regulations, Office of the Federal Register.

40 CFR 264.31, 2006, “Design and Operation of Facility,” Code of Federal Regulations, Office of the Federal Register.

40 CFR 264.32, 2006, “Required Equipment,” Code of Federal Regulations, Office of the Federal Register.

40 CFR 264.33, 2006, “Testing and Maintenance of Equipment,” Code of Federal Regulations, Office of the Federal Register.

40 CFR 264.34, 2006, “Access to Communications or Alarm System,” Code of Federal Regulations, Office of the Federal Register.

40 CFR 264.35, 2006, “Required Aisle Space,” Code of Federal Regulations, Office of the Federal Register.

40 CFR 264.171, 2006, “Condition of Containers,” Code of Federal Regulations, Office of the Federal Register.

40 CFR 264.172, 2006, “Compatibility of Waste with Containers,” Code of Federal Regulations, Office of the Federal Register.

40 CFR 264.173, 2006, “Management of Containers,” Code of Federal Regulations, Office of the Federal Register.

40 CFR 264.174, 2006, “Inspections,” Code of Federal Regulations, Office of the Federal Register.

40 CFR 264.175, 2006, “Containment,” Code of Federal Regulations, Office of the Federal Register.

40 CFR 264.176, 2006, “Special Requirements for Ignitable or Reactive Waste,” Code of Federal Regulations, Office of the Federal Register.

40 CFR 264.177, 2006, “Special Requirements for Incompatible Waste,” Code of Federal Regulations, Office of the Federal Register. 
40 CFR 268, 2006, “Land Disposal Restrictions,” Code of Federal Regulations, Office of the Federal Register.

40 CFR 268.40, 2006, “Applicability of Treatment Standards,” Code of Federal Regulations, Office of the Federal Register.

40 CFR 268.44, 2006, “Variance from a Treatment Standard,” Code of Federal Regulations, Office of the Federal Register.

40 CFR 268.45, “Treatment Standards for Hazardous Debris,” Code of Federal Regulations, Office of the Federal Register.

40 CFR 268.48, “Universal Treatment Standards,” Code of Federal Regulations, Office of the Federal Register.

40 CFR 268.49, 2006, “Alternative LDR Treatment Standards for Contaminated Soil,” Code of Federal Regulations, Office of the Federal Register.

40 CFR 273, 2006, “Standards for Universal Waste Management,” Code of Federal Regulations, Office of the Federal Register.

40 CFR 300, 2006, “National Oil and Hazardous Substances Pollution Contingency Plan,” Code of Federal Regulations, Office of the Federal Register.

40 CFR 300.400, 2006, “Hazardous Substance Response, General,” Code of Federal Regulations, Office of the Federal Register.

40 CFR 300.415, 2006, “Removal Action,” Code of Federal Regulations, Office of the Federal Register.

40 CFR 300.440, 2006, “Procedures for Planning and Implementing Off-Site Response Actions," Code of Federal Regulations, Office of the Federal Register.

40 CFR 761, 2006, "Polychlorinated Biphenyls (PCBs) Manufacturing, Processing, Distribution in Commerce, and Use Prohibitions," Code of Federal Regulations, Office of the Federal Register.

40 CFR 761.3, 2006, “Definitions,” Code of Federal Regulations, Office of the Federal Register.

40 CFR 761.61(c), 2006, "Risked-Based Disposal Approval,” Code of Federal Regulations, Office of the Federal Register.

42 USC § 2011-2259, 1954, “Atomic Energy Act of 1954,” United States Code.

42 USC § 6901 et seq., 1976, "Resource Conservation and Recovery Act of 1976 (Solid Waste Disposal Act)," United States Code.

42 USC § 9601 et seq., 1980, “Comprehensive Environmental Response, Compensation and Liability Act of 1980 (CERCLA/Superfund),” United States Code.

49 CFR 173.124, “Class 4, Divisions 4.1, 4.2 and 4.3-Definitions” Code of Federal Regulations, Office of the Federal Register. 
ANSI/AIM BC1-1995, “Uniform Symbology Specification Code 39,” American National Standards Institute, Association for Automatic Identification and Mobility.

Arbon, Rod, 2005, CCP WIPP/RCRA Field Sampling and Analysis Plan for the Accelerated Retrieval Project for a Described Area within Pit 4, ICP/EXT-04-00329, CCP-PO-025, Rev. 1, Idaho Completion Project.

Becker, B. H., J. D. Burgess, K. J. Holdren, D. K. Jorgensen, S. O. Magnuson, and A. J. Sondrup, 1998, Interim Risk Assessment and Contaminant Screening for the Waste Area Group 7 Remedial Investigation, DOE/ID-10569, U.S. Department of Energy Idaho Operations Office.

DOE G 435.1-1, 1999, “Crosswalk Tables DOE Order 5820.2A vs. DOE Order 435.1/M 435.1-1,” U.S. Department of Energy.

DOE-ID, 1991, Federal Facility Agreement and Consent Order for the Idaho National Engineering Laboratory, Administrative Docket No. 1088-06-29-120, U.S. Department of Energy Idaho Operations Office; U.S. Environmental Protection Agency, Region 10; Idaho Department of Health and Welfare.

DOE-ID, 2004a, Engineering Evaluation/Cost Analysis for the Accelerated Retrieval of a Designated Portion of Pit 4, DOE/NE-ID-11146, Rev. 0, U.S. Department of Energy Idaho Operations Office.

DOE-ID, 2004b, Action Memorandum for the Accelerated Retrieval of a Described Area within Pit 4, DOE/NE-ID-11179, Rev. 0, U.S. Department of Energy Idaho Operations Office.

DOE-ID, 2004c, Quality Assurance Project Plan for Waste Area Groups 1, 2, 3, 4, 5, 6, 7, 10 and Deactivation, Decontamination, and Decommissioning, DOE/ID-10587, Rev. 8, U.S. Department of Energy Idaho Operations Office.

DOE-ID, 2005a, Idaho National Engineering and Environmental Laboratory Waste Acceptance Criteria, DOE/ID-10381, Rev. 21, U.S. Department of Energy Idaho Operations Office.

DOE-ID, 2005b, ICDF Complex Waste Acceptance Criteria, DOE/ID-10881, Rev. 2, U.S. Department of Energy Idaho Operations Office.

DOE O 435.1, 2001, “Radioactive Waste Management,” Change 1, U.S. Department of Energy.

DOE O 5400.5, 1993, "Radiation Protection of the Public and the Environment,” Change 2, U.S. Department of Energy.

EDF-4478, 2005, "Waste Inventory of the Described Area within Pit 4 for the Accelerated Retrieval Project within the Radioactive Waste Management Complex,” Rev. 3, Idaho National Engineering and Environmental Laboratory.

EDF-4692, 2004, “Air Emissions Evaluation for the Accelerated Retrieval Project for a Described Area within Pit 4,” Rev. 0, Idaho National Engineering and Environmental Laboratory.

EDF-5307, 2004, “Chemical Compatibility and Inventory Evaluation for the Accelerated Retrieval Project for a Described Area within Pit 4,” Rev. 0, Idaho National Engineering and Environmental Laboratory. 
Einerson, J. J. and R. W. Thomas, 1999, Pit 9 Estimated Inventory of Radiological and Nonradiological Constituents, INEEL/EXT-99-00602, Rev. 0, Idaho National Engineering and Environmental Laboratory.

EPA, Hazardous Waste Management Act/Resource Conservation and Recovery Act Permit for RWMC, Volume 5-INEEL, EPA ID No. ID4890008952.

EPA, 1988, Management of Remediation Waste Under RCRA, EPA 530-F-98-026, U.S. Environmental Protection Agency.

EPA, 1989, Superfund LDR Guide \#5, Determining When Land Disposal Restrictions (LDRs) Are Applicable to CERCLA Response Actions, OSWER Directive 9347.3-05FS, U.S. Environmental Protection Agency, Office of Solid Waste and Emergency Response.

Gurney, Lance, 2006, Health and Safety Plan for the Accelerated Retrieval Project, ICP/EXT-04-00209, Rev. 7, Idaho National Laboratory, Idaho Cleanup Project.

Holdren, K. Jean, Bruce H. Becker, Nancy L. Hampton, L. Don Koeppen, Swen O. Magnuson, T. J. Meyer, Gail L. Olson, and A. Jeffrey Sondrup, 2002, Ancillary Basis for Risk Analysis of the Subsurface Disposal Area, INEEL/EXT-02-01125, Idaho National Engineering and Environmental Laboratory.

ICP, 2005, Historical Background Report for Rocky Flats Plant Waste Shipped to the INEEL and Buried in the SDA from 1954 through 1971, ICP/EXT-04-00248, Rev. 1, North Wind, Inc. for Idaho National Laboratory, Idaho Completion Project.

IDAPA § 58.01.01.203, 1994, “Permit Requirements for New and Modified Stationary Sources,” Idaho Administrative Procedures Act, Idaho Department of Environmental Quality.

IDAPA § 58.01.01.203.02, 1994, “National Ambient Air Quality Standards,” Idaho Administrative Procedures Act, Idaho Department of Environmental Quality.

IDAPA § 58.01.01.210, 1995, “Demonstration of Preconstruction Compliance with Toxic Standards,” Idaho Administrative Procedures Act, Idaho Department of Environmental Quality.

IDAPA § 58.01.01.577, 1994, “Ambient Air Quality Standards for Specific Air Pollutants,” Idaho Administrative Procedures Act, Idaho Department of Environmental Quality.

IDAPA § 58.01.01.585, 1995, “Toxic Air Pollutants Non-Carcinogenic Increments,” Idaho Administrative Procedures Act, Idaho Department of Environmental Quality.

IDAPA § 58.01.01.586, 2001, “Toxic Air Pollutants Carcinogenic Increments,” Idaho Administrative Procedures Act, Idaho Department of Environmental Quality.

IDAPA § 58.01.01.625, 2000, “Visible Emissions,” Idaho Administrative Procedures Act, Idaho Department of Environmental Quality.

IDAPA § 58.01.01.650, 1994, “Rules for Control of Fugitive Dust,” Idaho Administrative Procedures Act, Idaho Department of Environmental Quality. 
IDAPA § 58.01.01.651, 1994, “Rules for Control of Fugitive Dust: General Rules,” Idaho Administrative Procedures Act, Idaho Department of Environmental Quality.

IDAPA § 58.01.05.005, 2006, “Identification and Listing of Hazardous Waste,” Idaho Administrative Procedures Act, Idaho Department of Environmental Quality.

IDAPA § 58.01.05.006, 2006, “Standards Applicable to Generators of Hazardous Waste,” Idaho Administrative Procedures Act, Idaho Department of Environmental Quality.

IDAPA § 58.01.05.008, 2006, "Standards for Owners and Operators of Hazardous Waste Treatment, Storage and Disposal Facilities,” Idaho Administrative Procedures Act, Idaho Department of Environmental Quality.

IDAPA § 58.01.05.011, 2006, “Land Disposal Restrictions,” Idaho Administrative Procedures Act, Idaho Department of Environmental Quality.

IDAPA § 58.01.11, 1997, “Ground Water Quality Rule,” Idaho Administrative Procedures Act, Idaho Department of Environmental Quality.

INEL, 1985, A History of the Radioactive Waste Management Complex at the Idaho National Engineering Laboratory, WM-F1-81-003, Rev. 3, Idaho National Engineering Laboratory.

Janke, D. H., 2000, U.S. Department of Energy - Idaho Operations Office, Idaho National Engineering and Environmental Laboratory Interim Pollution Prevention Plan, DOE/ID-10333(00), U.S. Department of Energy Idaho Operations Office.

McIlwain, Beth A., 2004, Data Quality Objectives for the Accelerated Retrieval Project for a Described Area within Pit 4, ICP/EXT-04-00515, Rev. 1, Idaho National Engineering and Environmental Laboratory, Idaho Completion Project.

McIlwain, Beth A., 2006, Field Sampling Plan for the Accelerated Retrieval Project I, ICP/EXT-04-00516, Rev. 6, Idaho National Laboratory, Idaho Cleanup Project.

MCP-135, 2006, “Document Management,” Rev. 19, Manual 1-Administration, Idaho National Laboratory, Idaho Cleanup Project.

MCP-1390, 2006, “Waste Generator Services Waste Management,” Rev. 1, Manual 17-Waste Management, Idaho National Laboratory, Idaho Cleanup Project.

MCP-2669, 2006, “Hazardous Material Shipping,” Rev. 10, Manual 17_Waste Management, Idaho National Laboratory, Idaho Cleanup Project.

MCP-2670, 2006, “Motor Carrier Operations,” Rev. 10, Manual 17_Waste Management, Idaho National Laboratory, Idaho Cleanup Project.

MCP-3475, 2006, “Temporary Storage of CERCLA-Generated Waste at the INL Site,” Rev. 4, Manual 8-Environmental Protection and Compliance, Idaho National Laboratory, Idaho Cleanup Project. 
NIST, 2006, "Specifications, Tolerances, and Other Technical Requirements for Weighing and Measuring Devices,” NIST Handbook 44, National Institute of Standards and Technology, Office of Weights and Measures.

PLN-114, 2005, “INEEL Emergency Plan Resource Conservation and Recovery Act (RCRA) Contingency Plan,” Rev. 24, Idaho National Laboratory.

PLN-852, 2003, “Quality Program Plan: Idaho Completion Project Transuranic Waste Management,” Rev. 1, Idaho National Engineering and Environmental Laboratory, Idaho Completion Project.

PRD-183, 2006, “Radiological Control Manual,” Rev. 9, Manual 15A—ICP Radiological Control, Idaho National Laboratory, Idaho Cleanup Project.

Preussner, Brian, Kirt Jamison, Matt Allred, Alan Yonk, and Bert Lilburn, 2004, Excavation Plan and Sequential Process Narrative for the Accelerated Retrieval Project for a Described Area within Pit 4, ICP/EXT-04-00283, Rev. 1, Idaho National Laboratory, Idaho Completion Project.

Ritter, Paul D., Brent N. Burton, and Jila Banaee, 2005, National Emission Standards for Hazardous Air Pollutants Radiological Monitoring Plan for Phases I and II of the Accelerated Retrieval Project, ICP/EXT-04-00389, Rev. 1, Idaho National Laboratory, Idaho Completion Project.

SAR-215, 2004, "Preliminary Safety Analysis Report for the Accelerated Retrieval Project at Area G of Pit 4 within the Radioactive Waste Management Complex,” Rev. 0, Idaho National Engineering and Environmental Laboratory, Idaho Completion Project.

STD-101, 2005, “Integrated Work Control Process,” Rev. 18, Manual 6-Maintenance, Idaho National Engineering Laboratory, Idaho Cleanup Project.

UN, 2005, United Nations Manual of Tests and Criteria, New York: United Nations Publications.

Wastren Energy Services, 2004, Central Characterization Project Acceptable Knowledge Summary Report for a Described Area in Pit 4 at the Idaho National Engineering and Environmental Laboratory, CPP-AK-INEEL-001, Rev. 1, Wastren Energy Services. 


\section{Appendix A}

\section{Applicable or Relevant and Appropriate Requirements}




\section{Appendix A}

\section{Applicable or Relevant and Appropriate Requirements}

The purpose of this appendix is to identify the ARARs for the ARP NTCRA.

As is appropriate for a CERCLA action, only the substantive provisions of the cited ARARs require implementation for the project. Specific ARAR citations and implementation information are provided in Table A-1. Retrieved waste streams may be stored in WMF-698, other CERCLA storage areas, or alternatively within the RCRA-permitted storage areas located within the RWMC Transuranic Storage Area. Storage of ARP waste within RCRA-permitted storage will require compliance with the requirements of the INL HWMA/RCRA Permit for RWMC (i.e., Volume 5) rather than the RCRA storage ARARs identified in this appendix. The WAC for storage of ARP-retrieved waste within WMF698 is located in Appendix B.

The ARARs implementation for a CERCLA removal action is prescribed by the National Contingency Plan (40 CFR 300). Removal actions must "to the extent practicable considering the exigencies of the situation, attain ARARs under federal environmental or state environmental or facility siting laws" [40 CFR 300.415(j)]. The same subsection of the National Contingency Plan further states, "in determining whether compliance with ARARs is practicable, the lead agency may consider appropriate factors, including (1) the urgency of the situation; and (2) the scope of the removal action to be conducted." Consideration of these factors is discussed in the following sections relative to the identification of appropriate ARARs for this NTCRA.

\section{CHEMICAL-SPECIFIC APPLICABLE OR RELEVANT AND APPROPRIATE REQUIREMENTS}

The chemical-specific ARARs identified in Table A-1 for this NTCRA primarily are limited to ARARs controlling air emissions from the site. Examples of chemical-specific ARARs that will be attained through the NTCRA include the requirements of Idaho's toxic air pollutant standards for releases of carcinogenic and other hazardous chemicals to the ambient air. For radionuclide emissions, the requirements of "National Emission Standards for Emissions of Radionuclides Other Than Radon from Department of Energy Facilities" (40 CFR 61, Subpart H) will apply. The provisions of Subpart H limit the effective dose equivalent from all DOE INL Site facilities to a level of $10 \mathrm{mrem} / \mathrm{year}$.

It is noted that the chemical-specific ARARs of the Idaho groundwater quality rules and associated maximum contaminant levels (Idaho Administrative Procedures Act [IDAPA] 58.01.11) are anticipated to be ARARs for the comprehensive OU 7-13/14 remedy, but are not relevant and appropriate to the limited scope of this NTCRA. This conclusion is based on the limited scope of the proposed NTCRA in the context of the overall OU 7-13/14 Program. As stated in the CERCLA Compliance with Other Laws Manual: Interim Final, “.... removal action may be conducted to remove a large number of leaking drums and associated contaminated soil. In this situation, because the removal focuses only on partial control, chemical-specific ARARs for groundwater restoration would not be considered" (EPA 1988). Other chemical-specific ARARs are presented in Table A-1. 


\section{LOCATION-SPECIFIC APPLICABLE OR RELEVANT AND APPROPRIATE REQUIREMENTS}

Location-specific requirements that may apply to the RAP relate to cultural resource requirements, such as those from the National Historic Preservation Act (16 USC $\S 470$ et seq., 2002). Although the SDA is a disturbed area with prior clearance, the associated regulations are considered ARARs, and substantive provisions must be addressed in the unlikely event that archaeological remains are encountered during excavation of overburden soil.

\section{ACTION-SPECIFIC APPLICABLE OR RELEVANT AND APPROPRIATE REQUIREMENTS}

Substantive RCRA generator requirements for hazardous waste identification and management are applicable to waste that is retrieved and generated as part of the removal action. Based on project AK documentation, the waste forms from RFP are associated with various listed and characteristic HWNs based on similarity to the RFP waste stored elsewhere at RWMC.

The requirements for container storage (40 CFR 264, Subpart I) are identified as ARARs to address the CERCLA storage of containerized waste within the ARP area of contamination. Building WMF-698 will satisfy the substantive Subpart I requirements for storage of hazardous waste as modified in this document. The container array will be modified to a dense pack array. The dense pack array allows containers to be stored four containers wide. This configuration provides some radiation shielding, provides for the storage of more containers in a given storage space, and is supported by the containers generally being recently filled and generally containing no liquids. In addition to WMF-698, other storage areas are planned for use to store containerized secondary and other CERCLA waste as needed. These other areas consist of container storage areas, including cargo containers, boxes, or drums. The cargo containers would be approximately $2.4 \times 2.4 \times 6.1$-m $(8 \times 8 \times 20-\mathrm{ft})$. All CERCLA storage areas would be registered as CERCLA waste storage areas under INL Site MCPs and managed in accordance with the ARARs identified in this appendix. The CERCLA storage areas would be located onsite at RWMC.

The RCRA land disposal restrictions (LDRs) prohibit placing restricted RCRA hazardous waste in land-based units, such as landfills, surface impoundments, and waste piles, until treated to standards considered protective for disposal. Specific treatment standards are included in requirements. These requirements are applicable to the treatment and disposal of RCRA hazardous waste if placement of restricted waste occurs. The LDRs do not apply to materials disposed of at WIPP based on the WIPP Land Withdrawal Act exemption. The LDRs generally will apply to treated waste, secondary waste streams, other waste that is RCRA listed, or characteristic waste that is disposed of at off-INL Site treatment, storage, and disposal facilities.

The RCRA closure requirements for landfills are not considered ARARs for the limited scope of this removal action. As referenced above, the limited scope of the removal action can be considered in determining whether an ARAR is practicable for implementation in a removal action context. In the case of the proposed Alternative Two-Focused Retrieval, DOE has determined that implementation of closure ARARs is not practicable. The area of contamination (AOC) for WAG 7 has not been formally defined in CERCLA documentation under the Federal Facility Agreement and Consent Order for the INEL (DOE-ID 1991). For the purposes of this NTCRA, the AOC encompasses the SDA as bounded by the flood control dike that surrounds the SDA perimeter. As defined in Superfund LDR Guide \#5: Determining When Land Disposal Restrictions (LDRs) are Applicable to CERCLA Response Actions (EPA 1989), an AOC is delineated by the area extent (or boundary) of contiguous contamination. Such contamination must be continuous but may contain varying types and concentrations of hazardous 
substances. The AOC does not include any contaminated surface or groundwater that may be associated with the land-based waste source. Accordingly, the SDA AOC designation for this NTCRA is based on the presence of a continuous plume of volatile organic contamination in the SDA subsurface. Although this continuous volatile organic contaminant plume extends beyond the SDA boundary, the AOC is limited to the confines of the SDA for the purposes of implementing this NTCRA.

Implementation of closure requirements and associated monitoring provisions is not meaningful considering the limited portion of the overall landfill (i.e., SDA) being retrieved and considering that final closure ARARs for the ARP retrieval area and buildings will be satisfied through the OU 7-13/14 ROD or other CERCLA documentation prepared in the future (e.g., in the event subsequent removal actions are performed). It is not possible to construct a meaningful closure scenario for the retrieved area considering the scope of the retrieval being proposed and the magnitude of surrounding existing waste forms that are not addressed by the action.

The thermal treatment process to be potentially employed for treatment of VOCs will be subject to substantive ARARs as a miscellaneous unit under RCRA. As part of Subpart X implementation, additional substantive ARAR provisions deemed necessary to protect human health and the environment will be identified through consultation among DOE, DEQ, and EPA representatives as part of the removal action treatment design process. Additional ARARs for consideration include provisions of Subparts I through O and Subparts AA through CC of this part, Part 270, Part 63 Subpart EEE, and Part 146 of this chapter that are appropriate for the miscellaneous unit (i.e., thermal treatment unit) and the site-specific circumstances of the CERCLA action. These ARARs may include, but are not limited to, preparing a screening level risk assessment (SLRA) work plan, a preliminary SLRA, an emissions test plan, or a final SLRA that takes the maximally achievable control technology standards into consideration.

The TSCA regulations of "Polychlorinated Biphenyls (PCBs) Manufacturing, Processing, Distribution in Commerce, and Use Prohibitions" (40 CFR 761) governing management, characterization, storage, treatment, and disposal requirements for PCB remediation waste are applicable. Inventory information indicates that, although not expected, there is a potential for PCB contamination in the Pit 4 retrieval area waste inventory at concentrations above the TSCA regulatory threshold for PCBs (i.e., $50 \mathrm{ppm}$ or greater). The TSCA storage ARARs must be satisfied for any portion of the waste population identified to contain PCBs at 50 ppm or greater. This requirement may be met through a risk-based storage approval process as allowed by "PCB Remediation Waste" (40 CFR 761.61[c]). In the event that excavated waste-zone waste is identified to contain PCBs greater than $50 \mathrm{ppm}$, the waste will not be eligible for return to the pit without supportive risk-based documentation that proves otherwise; therefore, this waste will be placed in CERCLA storage.

The DEQ regulations for fugitive dust emissions are applicable to fugitive dust generated during remediation or construction activities. Dust suppressant (e.g., Soiltac) or water will be applied for fugitive dust control. In addition, DEQ visible emission standards are identified as ARARs. The requirements prohibit discharge of any air pollutant into the atmosphere from any point of emission for a period or periods aggregating more than 3 minutes in any 60 -minute period that is greater than $20 \%$ opacity.

Relevant substantive requirements of "Radiation Protection of the Public and the Environment" (DOE O 5400.5) and "Radioactive Waste Management" (DOE O 435.1), which specify DOE radiation protection and management requirements, will be met as TBC requirements. 
Table A-1. Applicable or relevant and appropriate requirements evaluation summary.

\begin{tabular}{|c|c|c|c|c|c|}
\hline $\begin{array}{l}\text { Item } \\
\text { Number }\end{array}$ & $\begin{array}{l}\text { ARARs or TBC } \\
\text { Requirements }\end{array}$ & Regulatory Citation & Type & Relevancy $^{\mathrm{a}}$ & $\begin{array}{l}\text { Implementation of Applicable or Relevant and } \\
\text { Appropriate Requirement Description }\end{array}$ \\
\hline \multirow[t]{4}{*}{1} & $\begin{array}{l}\text { Idaho Toxic Air } \\
\text { Pollutants }\end{array}$ & $\begin{array}{l}\text { IDAPA 58.01.01.585 } \\
\text { IDAPA 58.01.01.586 }\end{array}$ & Chemical & A & $\begin{array}{l}\text { Estimation of ARP toxic air pollutant emissions is performed consistent } \\
\text { with the process outlined in IDAPA 58.01.01.203 (“Permit } \\
\text { Requirements for New and Modified Stationary Sources”) and } \\
\text { IDAPA 58.01.01.210 (“Demonstration of Preconstruction Compliance } \\
\text { with Toxic Standards”). Through the use of the EPA-approved computer } \\
\text { model ISCST3, the following conclusions were made concerning } \\
\text { compliance with the Idaho Toxic Air Pollutants requirements } \\
\text { (EDF-4692, “Air Emissions Evaluation for the Accelerated Retrieval } \\
\text { Project for a Described Area within Pit 4"): }\end{array}$ \\
\hline & & & & & $\begin{array}{l}\text { Particulate emissions, as a measure of nonvolatile contaminants, } \\
\text { from ARP activities are not expected to result in a release of any } \\
\text { nonvolatile toxic air pollutants known to be in Pit } 4 \text { waste in excess } \\
\text { of IDAPA 58.01.01.585 and } 586 \text { emission limits. }\end{array}$ \\
\hline & & & & & $\begin{array}{l}\text { The volatile contaminant of concern was determined to be carbon } \\
\text { tetrachloride. The estimated annual emission rate of } 1.95 \mathrm{~g} / \mathrm{s} \text { for } \\
\text { carbon tetrachloride exceeds the screening emission level of } \\
5.55 \mathrm{E}-05 \mathrm{~g} / \mathrm{s} \text {; however, the modeled ambient concentration is } \\
\text { projected at } 4.5 \mathrm{E}-01 \mu \mathrm{g} / \mathrm{m}^{3} \text {, which is below the short-term, } \\
\text { adjusted acceptable ambient concentration level of } 6.7 \mathrm{E}-01 \mu \mathrm{g} / \mathrm{m}^{3} \text {. } \\
\text { It is assumed that demonstration of compliance with emission } \\
\text { limits for carbon tetrachloride provides a demonstration of } \\
\text { compliance with all other volatile contaminants potentially present } \\
\text { in the ARP waste. }\end{array}$ \\
\hline & & & & & $\begin{array}{l}\text { - The estimated cancer risks from carbon tetrachloride emissions to } \\
\text { the public and the maximally exposed RWMC worker are } \\
\text { 9.24E-09 and 6.52E-06, respectively. In interpreting estimates of } \\
\text { cancer risk, CERCLA generally considers action to be warranted } \\
\text { when risks exceed a target risk level of 1E-04. }\end{array}$ \\
\hline
\end{tabular}


Table A-1. (continued).

\begin{tabular}{|c|c|c|c|c|c|}
\hline $\begin{array}{l}\text { Item } \\
\text { Number }\end{array}$ & $\begin{array}{l}\text { ARARs or TBC } \\
\text { Requirements }\end{array}$ & Regulatory Citation & Type & Relevancy $^{\mathrm{a}}$ & $\begin{array}{l}\text { Implementation of Applicable or Relevant and } \\
\text { Appropriate Requirement Description }\end{array}$ \\
\hline \multirow[t]{4}{*}{2} & $\begin{array}{l}\text { Idaho Ambient } \\
\text { Air Quality } \\
\text { Standards for } \\
\text { Specific Air } \\
\text { Pollutants }\end{array}$ & IDAPA 58.01.01.577 & Chemical & A & $\begin{array}{l}\text { Estimation of ARP criteria pollutant emissions is performed consistent } \\
\text { with the process outlined in IDAPA 58.01.01.203 and } \\
\text { IDAPA 58.01.01.203.02 ("National Ambient Air Quality Standards"). } \\
\text { Through use of the EPA-approved computer model ISCST3, the } \\
\text { following conclusions were made concerning compliance with the } \\
\text { "Idaho Ambient Air Quality Standards for Specific Air Pollutants" } \\
\text { requirements: }\end{array}$ \\
\hline & & & & & $\begin{array}{l}\text { - Uncontrolled criteria air pollutant emissions from diesel-fired } \\
\text { fuel-burning equipment will not occur in excess of IDAPA } \\
\text { significance levels providing that the maximum continuous } \\
\text { fuel-burning equipment used is limited to 5,660 hour per year or } \\
\text { less. }\end{array}$ \\
\hline & & & & & $\begin{array}{l}\text { - Unabated ambient impact from criteria air pollutant emissions, } \\
\text { considering simultaneous operation of all fuel-burning equipment, } \\
\text { will not cause a violation of an Idaho or National Ambient Air } \\
\text { Quality Standard. }\end{array}$ \\
\hline & & & & & $\begin{array}{l}\text { - Potential uncontrolled toxic air pollutant emissions from } \\
\text { fuel-burning equipment are less than IDAPA screening emission } \\
\text { levels and/or less than IDAPA acceptable ambient concentrations. }\end{array}$ \\
\hline
\end{tabular}


Table A-1. (continued).

\begin{tabular}{|c|c|c|c|c|c|}
\hline $\begin{array}{l}\text { Item } \\
\text { Number }\end{array}$ & $\begin{array}{l}\text { ARARs or TBC } \\
\text { Requirements }\end{array}$ & Regulatory Citation & Type & Relevancy $^{\mathrm{a}}$ & $\begin{array}{l}\text { Implementation of Applicable or Relevant and } \\
\text { Appropriate Requirement Description }\end{array}$ \\
\hline \multirow[t]{2}{*}{3} & \multirow[t]{2}{*}{$\begin{array}{l}\text { National } \\
\text { Emission } \\
\text { Standards for } \\
\text { Emissions of } \\
\text { Radionuclides } \\
\text { other than Radon } \\
\text { from DOE } \\
\text { Facilities }\end{array}$} & \multirow[t]{2}{*}{$\begin{array}{l}\text { 40 CFR } 61.92 \text { through } \\
94 \text {, Subpart } \mathrm{H}\end{array}$} & \multirow[t]{2}{*}{ Chemical } & \multirow[t]{2}{*}{ A } & $\begin{array}{l}\text { Radionuclide emissions, the abated EDE for the INL Site maximally } \\
\text { exposed individual, and the unabated EDE for the INL Site maximally } \\
\text { exposed individual were determined using the EPA approved computer } \\
\text { model CAP-88. } \\
\text { It was determined that the abated EDE to the INL Site maximally } \\
\text { exposed individual from operations associated with ARP activities is } \\
\text { estimated at } 2.7 \mathrm{E}-02 \mathrm{mrem} / \mathrm{yr} \text {, which is a factor of } 370 \text { times lower than } \\
\text { the } 40 \text { CFR } 61.92 \mathrm{standard} \text { of } 10 \mathrm{mrem} / \mathrm{yr} \text {. }\end{array}$ \\
\hline & & & & & $\begin{array}{l}\text { Per } 40 \text { CFR } 61.93 \text {, sources with unmitigated potential emissions } \\
\text { determined to equal or exceed } 0.1 \text { mrem/yr are required to be } \\
\text { continuously monitored. Per CAP- } 88 \text { modeling, the unabated EDE to the } \\
\text { INL Site maximally exposed individual is estimated to be } 5.0 \mathrm{mrem} / \mathrm{yr} \text {, } \\
\text { thus the requirement for continuous air monitoring is applicable. In } \\
\text { accordance with } 40 \text { CFR } 61.93 \text {, all radionuclides that could contribute } \\
\text { greater than } 10 \% \text { of the potential EDE are required to be monitored. For } \\
\text { the ARP, the radionuclides requiring continuous monitoring are } \\
\text { determined to be Am-241, Pu-239, and Pu-240 (National Emission } \\
\text { Standards for Hazardous Air Pollutants Radiological Monitoring Plan } \\
\text { for the Accelerated Retrieval Project [Ritter, Burton, and Banaee } \\
\text { 2005]). }\end{array}$ \\
\hline \multirow[t]{2}{*}{4} & \multirow[t]{2}{*}{$\begin{array}{l}\text { National Historic } \\
\text { Preservation Act } \\
\text { of } 1966\end{array}$} & \multirow[t]{2}{*}{$\begin{array}{l}16 \text { USC } 470 \text { et seq., } \\
2002\end{array}$} & \multirow[t]{2}{*}{ Location } & \multirow[t]{2}{*}{ RA } & $\begin{array}{l}\text { The Subsurface Disposal Area is identified as a disturbed area with prior } \\
\text { clearance; therefore, it is expected that ARARs associated with the } \\
\text { National Historic Preservation Act will not require implementation. In } \\
\text { the event that archaeological remains are encountered during overburden } \\
\text { removal, specific requirements will be evaluated to determine the } \\
\text { appropriate action required to comply with the National Historic } \\
\text { Preservation Act through coordination with INL cultural resources } \\
\text { office personnel }\end{array}$ \\
\hline & & & & & $\begin{array}{l}\text { NOTE: None was identified during the overburden removal performed } \\
\text { by construction completed the week of May 17, } 2004 .\end{array}$ \\
\hline 5 & $\begin{array}{l}\text { Idaho Control of } \\
\text { Fugitive Dust } \\
\text { Emissions }\end{array}$ & $\begin{array}{l}\text { IDAPA 58.01.01.650 } \\
\text { IDAPA 58.01.01.651 }\end{array}$ & Action & A & $\begin{array}{l}\text { Control of fugitive dust emissions during construction and operational } \\
\text { activities is controlled via the use of dust suppressant or water, as } \\
\text { needed, to control emissions below a particulate matter of } 10 \text { microns } \\
\text { based on a significant emission limit of } 15 \text { tons/year. }\end{array}$ \\
\hline
\end{tabular}


Table A-1. (continued).

\begin{tabular}{|c|c|c|c|c|c|}
\hline $\begin{array}{l}\text { Item } \\
\text { Number }\end{array}$ & $\begin{array}{l}\text { ARARs or TBC } \\
\text { Requirements }\end{array}$ & Regulatory Citation & Type & Relevancy $^{\mathrm{a}}$ & $\begin{array}{l}\text { Implementation of Applicable or Relevant and } \\
\text { Appropriate Requirement Description }\end{array}$ \\
\hline 6 & $\begin{array}{l}\text { Idaho Visible } \\
\text { Emissions }\end{array}$ & IDAPA 58.01.01.625 & Action & A & $\begin{array}{l}\text { All sources of emissions for the ARP will be evaluated, and opacity } \\
\text { readings will be performed as required. }\end{array}$ \\
\hline \multirow[t]{2}{*}{7} & HWD & $\begin{array}{l}\text { IDAPA 58.01.05.006 } \\
\text { (40 CFR 262.11) }\end{array}$ & Action & A & $\begin{array}{l}\text { An HWD will be performed during retrieval activities for retrieved } \\
\text { waste primarily through visual examination and AK. Sampling and } \\
\text { analysis will be performed per an established plan. }\end{array}$ \\
\hline & & & & & $\begin{array}{l}\text { An HWD, performed by Waste Generator Services, for secondary waste } \\
\text { to be disposed of off the INL Site, will be performed through AK of the } \\
\text { waste with which the secondary waste has come in contact. Sampling } \\
\text { and analysis will be performed, if required. }\end{array}$ \\
\hline 8 & $\begin{array}{l}\text { Standards for } \\
\text { Owners and } \\
\text { Operators of } \\
\text { Treatment, } \\
\text { Storage, and } \\
\text { Disposal } \\
\text { Facilities-Use } \\
\text { and Management } \\
\text { of Containers }\end{array}$ & $\begin{array}{l}\text { IDAPA 58.01.05.008 } \\
\text { (40 CFR 264, Subpart I) }\end{array}$ & & & (See items that follow.) \\
\hline
\end{tabular}


Table A-1. (continued).

\begin{tabular}{|c|c|c|c|c|c|}
\hline $\begin{array}{l}\text { Item } \\
\text { Number }\end{array}$ & $\begin{array}{l}\text { ARARs or TBC } \\
\text { Requirements }\end{array}$ & Regulatory Citation & Type & Relevancy $^{\mathrm{a}}$ & $\begin{array}{l}\text { Implementation of Applicable or Relevant and } \\
\text { Appropriate Requirement Description }\end{array}$ \\
\hline \multirow[t]{4}{*}{$8 a$} & $\begin{array}{l}\text { Condition of } \\
\text { Containers }\end{array}$ & $\begin{array}{l}\text { IDAPA 58.01.05.008 } \\
(40 \text { CFR 264.171) }\end{array}$ & Action & A & $\begin{array}{l}\text { As noted previously, all waste will be in new containers. Weekly } \\
\text { inspections of CERCLA storage areas will be performed in accordance } \\
\text { with INL Site management control procedures. A modified inspection } \\
\text { approach is required for CERCLA waste stored in a modified dense } \\
\text { pack arrangement as discussed directly below. }\end{array}$ \\
\hline & & & & & $\begin{array}{l}\text { The following requirements apply only to waste stored in a modified } \\
\text { dense pack arrangement in WMF-698. }\end{array}$ \\
\hline & & & & & $\begin{array}{l}\text { A weekly inspection for leaks and spills will be performed by an } \\
\text { inspector walking around the perimeter of the container rows in } \\
\text { WMF-698. Additionally, weekly radiological surveys (e.g., swipes, } \\
\text { instrument monitoring) will be performed on any suspected leak/spill or } \\
\text { any container observed with damage that could impact container } \\
\text { integrity. If leaks/spills and/or radiological contamination are found, } \\
\text { then corrective action will be performed on a timely basis. }\end{array}$ \\
\hline & & & & & $\begin{array}{l}\text { A quarterly inspection will be performed by visually inspecting for any } \\
\text { liquid present on or near the containers and for signs of defective, } \\
\text { visibly pitted, metal-fatigued, or deteriorated containers. This inspection } \\
\text { will be performed around the perimeter of the container rows and } \\
\text { through each aisle in between the rows of containers. }\end{array}$ \\
\hline $8 b$ & $\begin{array}{l}\text { Compatibility of } \\
\text { Waste with } \\
\text { Containers }\end{array}$ & $\begin{array}{l}\text { IDAPA 58.01.05.008 } \\
\text { (40 CFR 264.172) }\end{array}$ & Action & A & $\begin{array}{l}\text { Containers used in all CERCLA storage areas will be compatible with } \\
\text { the types of waste managed. }\end{array}$ \\
\hline
\end{tabular}


Table A-1. (continued).

\begin{tabular}{|c|c|c|c|c|c|}
\hline $\begin{array}{l}\text { Item } \\
\text { Number }\end{array}$ & $\begin{array}{l}\text { ARARs or TBC } \\
\text { Requirements }\end{array}$ & Regulatory Citation & Type & Relevancy $^{\mathrm{a}}$ & $\begin{array}{l}\text { Implementation of Applicable or Relevant and } \\
\text { Appropriate Requirement Description }\end{array}$ \\
\hline \multirow[t]{6}{*}{$8 \mathrm{c}$} & $\begin{array}{l}\text { Management of } \\
\text { Containers }\end{array}$ & $\begin{array}{l}\text { IDAPA 58.01.05.008 } \\
\text { (40 CFR 264.173) }\end{array}$ & Action & A & $\begin{array}{l}\text { Containers being stored will be kept closed at all times, except when } \\
\text { adding or removing waste. Vented containers are considered closed, if } \\
\text { vents are installed per the manufacturer's recommendations. In general, } \\
\text { all transuranic waste containers stored in the CERCLA storage areas are } \\
\text { vented. }\end{array}$ \\
\hline & & & & & $\begin{array}{l}\text { Containers will be managed in such a way to prevent conditions that } \\
\text { may rupture the container or cause it to leak. }\end{array}$ \\
\hline & & & & & $\begin{array}{l}\text { The following criteria apply only to waste stored in a modified dense } \\
\text { pack arrangement in WMF-698: }\end{array}$ \\
\hline & & & & & $\begin{array}{l}\text { Quarterly inspections will be performed to verify that containers } \\
\text { are positioned properly and properly located in the storage } \\
\text { configuration. }\end{array}$ \\
\hline & & & & & $\begin{array}{l}\text { - } \quad \text { Rows of drums in WMF- } 698 \text { are no more than } 4 \text { drums wide by } \\
5 \text { drums high by } 28 \text { in length. }\end{array}$ \\
\hline & & & & & Aisle spacing requirements will be maintained. \\
\hline $8 d$ & Inspections & $\begin{array}{l}\text { IDAPA 58.01.05.008 } \\
\text { (40 CFR 264.174) }\end{array}$ & Action & A & $\begin{array}{l}\text { At least weekly, inspections of the area where containers are stored will } \\
\text { be performed. For additional information on inspections being } \\
\text { performed, see items numbered 8a, 8c, 8e, 10,12b, 12c, and 12e. }\end{array}$ \\
\hline
\end{tabular}


Table A-1. (continued).

\begin{tabular}{|c|c|c|c|c|c|}
\hline $\begin{array}{l}\text { Item } \\
\text { Number }\end{array}$ & $\begin{array}{l}\text { ARARs or TBC } \\
\text { Requirements }\end{array}$ & Regulatory Citation & Type & Relevancy $^{\mathrm{a}}$ & $\begin{array}{l}\text { Implementation of Applicable or Relevant and } \\
\text { Appropriate Requirement Description }\end{array}$ \\
\hline \multirow[t]{2}{*}{$8 e$} & Containment & $\begin{array}{l}\text { IDAPA 58.01.05.008 } \\
\text { (40 CFR 264.175) }\end{array}$ & Action & A & $\begin{array}{l}\text { In general, containers with free liquid will not require storage in the } \\
\text { CERCLA storage areas because limited quantities of free liquid are } \\
\text { expected to be encountered and retrieved from the pit. Additionally, if } \\
\text { free liquids are retrieved and sent with waste to the waste processing } \\
\text { drum packaging station, then it is expected that the free liquid will be } \\
\text { observed during the visual examination and absorbed. If containerized } \\
\text { free liquids are stored in the CERCLA storage areas, then portable } \\
\text { secondary pallets/pans will be used for those containers that have the } \\
\text { capacity to contain a minimum of } 10 \% \text { of the volume of the containers } \\
\text { located on the spill pallet/pan or the volume of the largest container, } \\
\text { whichever is greater. Containerized free liquids will not be stored } \\
\text { outdoors in unenclosed areas. Note that some free liquids from } \\
\text { secondary waste streams (e.g., hydraulic fluids, diesel, oils) will be } \\
\text { generated and will be stored on spill pallets for containment, as needed. } \\
\text { If stored outside, this waste will be covered with tarps, as appropriate. }\end{array}$ \\
\hline & & & & & $\begin{array}{l}\text { Monthly inspections of the spill pallets/pans will be performed, looking } \\
\text { for evidence of significant cracks and gaps that may compromise the } \\
\text { integrity of the containment. Weekly visual inspections also will be } \\
\text { performed to verify that no liquid is present in the containment system } \\
\text { of the spill pallet/pan. }\end{array}$ \\
\hline $8 f$ & $\begin{array}{l}\text { Special } \\
\text { Requirements } \\
\text { for Ignitable or } \\
\text { Reactive Waste }\end{array}$ & $\begin{array}{l}\text { IDAPA 58.01.05.008 } \\
\text { (40 CFR 264.176) }\end{array}$ & Action & A & $\begin{array}{l}\text { The facility boundary line is defined as the INL Site boundary. The } \\
\text { RWMC is } 3 \text { miles from the southern INL Site boundary, which is the } \\
\text { closest boundary to RWMC. Therefore, the waste stored in the storage } \\
\text { units is more than } 15 \mathrm{~m}(50 \mathrm{ft}) \text { from the INL Site boundary. }\end{array}$ \\
\hline $8 g$ & $\begin{array}{l}\text { Special } \\
\text { Requirements } \\
\text { for Incompatible } \\
\text { Wastes }\end{array}$ & $\begin{array}{l}\text { IDAPA 58.01.05.008 } \\
\text { (40 CFR 264.177) }\end{array}$ & Action & A & $\begin{array}{l}\text { In general, incompatible wastes are not stored in the CERCLA storage } \\
\text { areas. In the event that incompatible wastes are stored, then containers } \\
\text { holding incompatible wastes will be separated via distance (i.e., located } \\
\text { in separate rows) if the wastes contain no free liquids. If the } \\
\text { incompatible wastes contain free liquids, then the wastes will be } \\
\text { segregated through use of separate spill pallets/pans. }\end{array}$ \\
\hline
\end{tabular}


Table A-1. (continued).

\begin{tabular}{|c|c|c|c|c|c|}
\hline $\begin{array}{l}\text { Item } \\
\text { Number }\end{array}$ & $\begin{array}{l}\text { ARARs or TBC } \\
\text { Requirements }\end{array}$ & Regulatory Citation & Type & Relevancy $^{\mathrm{a}}$ & $\begin{array}{l}\text { Implementation of Applicable or Relevant and } \\
\text { Appropriate Requirement Description }\end{array}$ \\
\hline 9 & $\begin{array}{l}\text { General Waste } \\
\text { Analysis }\end{array}$ & $\begin{array}{l}\text { IDAPA 58.01.05.008 } \\
\text { [40 CFR 264.13(a)(1) } \\
\text { and (a)(2)] }\end{array}$ & Action & A & $\begin{array}{l}\text { Chemical and physical characterization will be performed for Pit } 4 \\
\text { waste, per a set sampling regime via the CCP WIPP/RCRA Field } \\
\text { Sampling and Analysis Plan (Arbon 2005), during retrieval of the waste } \\
\text { and use of AK. The AK will consist of information gathered from the } \\
\text { generating facility and information from past retrieval activities } \\
\text { (e.g., Glovebox Excavator Method and Transuranic Storage Area) will } \\
\text { also be used for waste generated from similar processes. Additional } \\
\text { sampling and analysis will be performed, if required. }\end{array}$ \\
\hline \multirow[t]{2}{*}{10} & $\begin{array}{l}\text { General } \\
\text { Inspection } \\
\text { Requirements }\end{array}$ & $\begin{array}{l}\text { IDAPA 58.01.05.008 } \\
\text { [40 CFR 264.15(a) and } \\
\text { (c)] }\end{array}$ & Action & A & $\begin{array}{l}\text { Inspections of the areas where containers are stored will be performed } \\
\text { on items (e.g., malfunctions and deterioration) that may cause or lead to } \\
\text { (1) releases of hazardous waste constituents to the environment, or (2) a } \\
\text { threat to human health. Following completion of all inspections, any } \\
\text { identified problems requiring further action are corrected on a timely } \\
\text { basis. }\end{array}$ \\
\hline & & & & & $\begin{array}{l}\text { For additional information on inspections being performed, see items } \\
\text { numbered } 8 \mathrm{a}, 8 \mathrm{c}, 8 \mathrm{e}, 10,12 \mathrm{~b}, 12 \mathrm{c} \text {, and 12e. }\end{array}$ \\
\hline \multirow{4}{*}{11} & & & & & $\begin{array}{l}\text { Incompatible wastes, if placed into the CERCLA storage areas, are } \\
\text { segregated as discussed earlier. }\end{array}$ \\
\hline & & & & & $\begin{array}{l}\text { Routine inspections of the CERCLA storage areas provide regular } \\
\text { assessment of storage conditions and early identification of potentially } \\
\text { hazardous situations. }\end{array}$ \\
\hline & & & & & Malfunctioning equipment is tagged and either locked out or isolated. \\
\hline & & & & & $\begin{array}{l}\text { Waste is stored in containers that are kept closed at all times, except } \\
\text { when adding or removing waste. }\end{array}$ \\
\hline
\end{tabular}


Table A-1. (continued).

\begin{tabular}{|c|c|c|c|c|c|}
\hline $\begin{array}{l}\text { Item } \\
\text { Number }\end{array}$ & $\begin{array}{l}\text { ARARs or TBC } \\
\text { Requirements }\end{array}$ & Regulatory Citation & Type & Relevancy $^{\mathrm{a}}$ & $\begin{array}{l}\text { Implementation of Applicable or Relevant and } \\
\text { Appropriate Requirement Description }\end{array}$ \\
\hline $12 \mathrm{a}$ & $\begin{array}{l}\text { Design and } \\
\text { Operation of } \\
\text { Facility }\end{array}$ & $\begin{array}{l}\text { IDAPA 58.01.05.008 } \\
(40 \text { CFR 264.31) }\end{array}$ & Action & A & $\begin{array}{l}\text { The ARP buildings are designed, constructed, maintained, and operated } \\
\text { in such a manner as to minimize the possibility of a fire, explosion, or } \\
\text { any unplanned sudden or nonsudden release of hazardous waste } \\
\text { constituents to the air, soil, or surface water that could threaten human } \\
\text { health or the environment. }\end{array}$ \\
\hline \multirow[t]{4}{*}{$12 b$} & $\begin{array}{l}\text { Required } \\
\text { Equipment }\end{array}$ & $\begin{array}{l}\text { IDAPA 58.01.05.008 } \\
(40 \text { CFR 264.32) }\end{array}$ & Action & A & $\begin{array}{l}\text { Two-way radios or cell phones will be used by personnel such that } \\
\text { immediate emergency instructions may be given to all affected } \\
\text { personnel. The two-way radios or cell phone also will be used to } \\
\text { summon emergency assistance from local police departments, fire } \\
\text { departments, and/or state or local emergency response teams. A } \\
\text { two-way radio or cell phone will be worn by at least one person during } \\
\text { all entries into the CERCLA storage areas. }\end{array}$ \\
\hline & & & & & $\begin{array}{l}\text { A minimum of four portable fire extinguishers will be present within } \\
\text { WMF-698, one extinguisher located in the vicinity of each personnel } \\
\text { access door. A monthly inspection will be performed to ensure that fire } \\
\text { extinguishers are in the proper location, easily accessible, and that there } \\
\text { is no evidence of damage or tampering. }\end{array}$ \\
\hline & & & & & $\begin{array}{l}\text { A minimum of one spill control equipment will be present in WMF-698. } \\
\text { If only solid waste is being stored within WMF-698, then the spill } \\
\text { control equipment will consist of a shovel, broom, plastic bag(s), and } \\
\text { overpack container. If containerized free liquids are stored, then an } \\
\text { absorbent material also will also be part of the spill control equipment in } \\
\text { addition to the items required for solid waste storage. A monthly } \\
\text { inspection will be performed to verify the presence of the spill control } \\
\text { equipment and the contents of the equipment. Any spill control } \\
\text { equipment needed for separate CERCLA waste storage areas (i.e., other } \\
\text { than WMF-698), will be as specified in the appropriate Appendix L. }\end{array}$ \\
\hline & & & & & $\begin{array}{l}\text { Water at adequate volume and pressure is available for the ARP } \\
\text { buildings via a fire hydrant to supply water hose systems. }\end{array}$ \\
\hline
\end{tabular}


Table A-1. (continued).

\begin{tabular}{|c|c|c|c|c|c|}
\hline $\begin{array}{l}\text { Item } \\
\text { Number }\end{array}$ & $\begin{array}{l}\text { ARARs or TBC } \\
\text { Requirements }\end{array}$ & Regulatory Citation & Type & Relevancy $^{\mathrm{a}}$ & $\begin{array}{l}\text { Implementation of Applicable or Relevant and } \\
\text { Appropriate Requirement Description }\end{array}$ \\
\hline $12 \mathrm{c}$ & $\begin{array}{l}\text { Testing and } \\
\text { Maintenance of } \\
\text { Equipment }\end{array}$ & $\begin{array}{l}\text { IDAPA 58.01.05.008 } \\
\text { (40 CFR 264.33) }\end{array}$ & Action & A & $\begin{array}{l}\text { All communication or alarm systems, fire protection equipment, spill } \\
\text { control equipment, and decontamination equipment, where required, } \\
\text { will be tested per a set schedule to ensure their proper operation in the } \\
\text { event of an emergency. Maintenance will be performed per } \\
\text { manufacturer's recommendations, regulatory requirements, or based } \\
\text { upon a reliability centered maintenance program. }\end{array}$ \\
\hline $12 \mathrm{e}$ & $\begin{array}{l}\text { Required Aisle } \\
\text { Space }\end{array}$ & $\begin{array}{l}\text { IDAPA 58.01.05.008 } \\
(40 \text { CFR 264.35) }\end{array}$ & Action & A & $\begin{array}{l}\text { A quarterly inspection will be performed in WMF- } 698 \text { to ensure that a } \\
\text { minimum of } 0.9 \mathrm{~m}(3 \mathrm{ft}) \text { of aisle space is maintained between rows of } \\
\text { containers and between the rows and all internal and external walls. } \\
\text { Additionally, a minimum of } 6.1 \mathrm{~m}(20 \mathrm{ft}) \text { will be maintained for the } \\
\text { center access aisle. Alternate storage configuration may be required for } \\
\text { special-case waste storage, such as incompatible waste or waste with } \\
\text { criticality considerations. }\end{array}$ \\
\hline \multirow[t]{2}{*}{14} & \multirow[t]{2}{*}{$\begin{array}{l}\text { Land Disposal } \\
\text { Restrictions- } \\
\text { Treatment } \\
\text { Standards }\end{array}$} & \multirow[t]{2}{*}{$\begin{array}{l}\text { IDAPA 58.01.05.011 } \\
\text { (40 CFR 268.40, 44, 45, } \\
\text { 48, and 49) }\end{array}$} & \multirow[t]{2}{*}{ Action } & \multirow[t]{2}{*}{ A } & $\begin{array}{l}\text { Waste disposed of at the Waste Isolation Pilot Plant is not required to } \\
\text { meet the land disposal restriction, given that the Waste Isolation Pilot } \\
\text { Plant has been granted a no migration variance. Waste profiles will be } \\
\text { developed for any waste disposed of at other disposal facilities and will } \\
\text { be treated to meet the appropriate treatment standards, as applicable. }\end{array}$ \\
\hline & & & & & $\begin{array}{l}\text { A site-specific risk-based treatability variance may be developed in } \\
\text { conjunction with the design of a treatment system, as applicable. }\end{array}$ \\
\hline
\end{tabular}


Table A-1. (continued).

\begin{tabular}{|c|c|c|c|c|c|}
\hline $\begin{array}{l}\text { Item } \\
\text { Number }\end{array}$ & $\begin{array}{l}\text { ARARs or TBC } \\
\text { Requirements }\end{array}$ & Regulatory Citation & Type & Relevancy $^{\mathrm{a}}$ & $\begin{array}{l}\text { Implementation of Applicable or Relevant and } \\
\text { Appropriate Requirement Description }\end{array}$ \\
\hline 15 & $\begin{array}{l}\text { Polychlorinated } \\
\text { Biphenyls } \\
\text { Storage and } \\
\text { Disposal }\end{array}$ & 40 CFR 761 & Action & A & $\begin{array}{l}\text { Inventory documentation indicates that polychlorinated biphenyls were } \\
\text { not a routine contaminant in Pit } 4 \text { waste streams, but may have been } \\
\text { placed in Pit } 4 \text { waste occasionally. In the event that polychlorinated } \\
\text { biphenyl contamination at } 50 \text { ppm or greater is generated, it may be } \\
\text { stored in WMF-698 in accordance with the risk-based storage approval } \\
\text { documented in the ARP Action Memorandum (DOE-ID 2004b). }\end{array}$ \\
\hline 16 & $\begin{array}{l}\text { Radioactive } \\
\text { Waste } \\
\text { Management }\end{array}$ & DOE Order 435.1 & Action & TBC & $\begin{array}{l}\text { The requirements of DOE Order } 435.1 \text { are implemented through the use } \\
\text { of various management control procedures for the INL Site. }\end{array}$ \\
\hline 17 & $\begin{array}{l}\text { Radiation } \\
\text { Protection of the } \\
\text { Public and the } \\
\text { Environment }\end{array}$ & DOE Order 5400.5 & $\begin{array}{l}\text { Action } \\
\text { and } \\
\text { Chemical }\end{array}$ & ТВС & $\begin{array}{l}\text { The requirements of DOE Order } 5400.5 \text { are implemented through the } \\
\text { use of various management control procedures for the INL Site. }\end{array}$ \\
\hline $\begin{array}{l}\text { a. Relevancy } \\
\text { AK }=\text { accept } \\
\text { ARP }=\text { Accel } \\
\text { ARAR }=\text { app } \\
\text { CERCLA = } \\
\text { CFR }=\text { Code } \\
\text { DOE }=\text { U.S. } \\
\text { EDE }=\text { effect } \\
\text { EPA = U.S. } \\
\text { HWD }=\text { haza } \\
\text { IDAPA = Ida } \\
\text { INL }=\text { Idaho } \\
\text { RWMC = Ra } \\
\text { TBC }=\text { to-be- }\end{array}$ & $\begin{array}{l}\text { fers to the type of requir } \\
\text { le knowledge } \\
\text { ated Retrieval Project } \\
\text { cable or relevant and app } \\
\text { mprehensive Environme } \\
\text { Federal Regulations } \\
\text { epartment of Energy } \\
\text { e dose equivalent } \\
\text { vironmental Protection } \\
\text { ous waste determination } \\
\text { Administrative Proced } \\
\text { ational Laboratory } \\
\text { oactive Waste Managem } \\
\text { nnsidered. }\end{array}$ & $\begin{array}{l}\text { ment: A= applicable, RA= rel } \\
\text { opriate requirement } \\
\text { ntal Resource, Compensation, } \\
\text { gency } \\
\text { res Act } \\
\text { ent Complex }\end{array}$ & Liability Act & e, or $\mathrm{TBC}=$ to-be & considered. \\
\hline
\end{tabular}


Appendix B

Waste Acceptance Criteria for WMF-698 


\section{Appendix B}

\section{Waste Acceptance Criteria for WMF-698}

The following WAC apply to waste to be stored in WMF-698 located in the SDA at RWMC and the CERCLA storage areas at RWMC that store waste from the ARP. New areas may be added as needed. These waste streams will include all waste retrieved from the ARP, as well as secondary and DD\&D waste.

Waste types that may be accepted include:

- $\quad$ TSCA-regulated waste

- $\quad$ CERCLA waste

- $\quad$ Mixed transuranic waste (MTRU) waste

- $\quad$ Mixed low-level waste

- $\quad$ TRU waste.

The purpose of this section is to define the requirements for accepting waste for storage in WMF-698 and other CERCLA storage areas at the RWMC. These requirements are based on relevant requirements from the RWMC HWMA/RCRA Part B Permit, DOE orders, RWMC safety basis, applicable CFRs, and off-INL Site disposal facility WAC.

Waste that does not meet the criteria in this section may be accepted by the facility manager for storage on a case-by-case basis following appropriate subject matter expert reviews and an evaluation of the waste and available information to ensure it meets the requirements of the facility authorization basis. Deviation from specific criteria (i.e., packaging criteria) requires DOE-ID approval in addition to facility manager approval. The case-by-case exemption will be documented via written correspondence (e.g., letter or e-mail) from the appropriate DOE and CH2M-WG Idaho, LLC, management personnel, and a hard copy of the approval letter will be included in the IWTS hard copy profile.

Waste generated from the ARP will be managed as CERCLA waste. The generator must comply with the applicable WAC for disposal for any newly generated waste. While in CERCLA storage, the WAC will apply in addition to the project-specific CERCLA ARARs.

\section{DOCUMENTATION REQUIREMENTS}

1. All waste will be characterized with available data and have appropriate hazardous waste codes identified (e.g., through process knowledge and/or sampling) before accepted for storage in WMF-698.

2. TRU waste with no identified path to disposal must be generated only in accordance with DOE Guide 435.1-1, Chapter III, H(2), and is managed on a case-by-case basis as approved by the facility manager.

3. An IWTS Material and Container Profile is required for storage in WMF-698. 
4. For TRU and MTRU waste, documentation must be entered into the Material Profile Comments Screen of IWTS that the waste is defense related and the waste is generated from "Defense nuclear waste and materials by-products management.”

5. CERCLA waste moved to WMF-698 from locations other than ARP must be certified, reviewed, and approved in IWTS prior to waste transfer.

\section{CONTAINER PROPERTIES}

1. Waste containers must be visually verified to be in good condition (e.g., no severe rusting or apparent structural defects) and free of leaks before being accepted into storage. If the container does not meet these criteria, the owner or operator must transfer the waste from this container to a container that is in good condition and meets the proper shipping requirements for this waste type, or manage the waste in some other way that complies with the requirements of 40 CFR 264, Subpart I.

2. The following containers are acceptable for storage in WMF-698:
a. 55-gal drums
b. 85-gal drums
c. Standard waste boxes
d. Metal boxes.

3. Each container shall comply with the weight limits shown in Table B-1. Calibration of the scales used to make these weight determinations shall be in accordance with the National Institute of Standards and Technology Handbook 44 (NIST 2006), or an equivalent standard.

Table B-1. Weight limits.

\begin{tabular}{lc}
\hline \multicolumn{1}{c}{ Container } & $\begin{array}{c}\text { Maximum Gross Weight } \\
(\mathrm{lb})\end{array}$ \\
\hline 55-gal drum & $\leq 1,000$ \\
85-gal drum containing one 55-gal drum & $\leq 1,000$ \\
Standard waste box & $\leq 4,000$ \\
Metal box & $<10,000$ \\
\hline
\end{tabular}

4. Removable surface contamination on contact-handled TRU waste containers shall not exceed $20 \mathrm{dpm} / 100 \mathrm{~cm}^{2}$ alpha and $1,000 \mathrm{dpm} / 100 \mathrm{~cm}^{2}$ beta-gamma.

5. Each container shall be labeled with a unique container identification number using bar code labels permanently attached in conspicuous locations. The container identification number shall be in medium to low density Code 39 bar code symbology as required by American National Standards Institute Standard ANSI/AIM BC1-1995 in characters at least $2.54 \mathrm{~cm}(1 \mathrm{in}$.) high and alphanumeric characters at least $1.27 \mathrm{~cm}$ (1/2 in.) high. In the case of 55- and 85-gal drums, the minimum of three bar code identification labels shall be placed at approximately equal intervals around the circumference of the drum (120 degrees for 3 labels and 90 degrees for 4 labels). In the 
case of standard waste boxes or metal boxes, bar code labels are required on the flat sides of the standard waste box or metal box.

6. Containers shall be marked "Caution Radioactive Material” using a yellow and magenta label as specified in 10 CFR 835.

7. For TRU waste, each container shall have one or more filter vents. These filter vents shall meet the specifications of the TRUPACT-II authorized methods for payload control (TRAMPAC) and contact-handled TRAMPAC, as applicable.

8. All containers containing CERCLA-generated waste shall be labeled with the words "CERCLA WASTE." For transfers to WMF-628 or WMF-610, all containers of mixed waste also shall be labeled with the words "HAZARDOUS WASTE."

9. For each container of CERCLA-generated waste, each IWTS material profile shall provide a description of the waste, operable unit, name and phone number of the generator point of contact, and a container description.

10. All containers located in WMF-698 shall be clearly marked with a waste generation date (date the waste was packaged or removed from service) that is visible for inspection.

11. Each PCB container shall be marked with the large PCB $\mathrm{M}_{\mathrm{L}}$ or $\mathrm{M}_{\mathrm{S}}$ mark.

12. PCB items shall be marked with the date the item was removed from service for disposal.

\section{CONTAINER CONTENTS}

1. All containers must adhere to the relevant safety analysis report, fire hazards analysis, and criticality safety evaluation requirements to ensure safe storage. The current revision of the relevant safety analysis report, fire hazards analysis, and criticality safety evaluation must be consulted for storage and spacing requirements.

2. The total residual liquid in any container shall not exceed $1 \%$ by volume of that container.

3. Containers shall be verified to be free of sealed containers greater than $4 \mathrm{~L}$.

4. Pyrophoric radioactive materials shall be present only in small residual amounts (less than $1 \%$ by weight) in containers and shall be generally dispersed.

5. Waste exhibiting the characteristic of reactivity (EPA HWN D003) is not acceptable unless approved on a case-by-case basis in writing as noted above.

6. Waste containing incompatible materials may be stored on a case-by-case basis. Containers holding incompatible waste will require separation via distance (i.e., located in separate rows) or barrier.

7. Waste containing materials incompatible with container and packaging materials are not acceptable.

8. Waste shall contain no explosive, corrosive, or compressed gases (pressurized containers). 
9. Active pathogens, infectious substances, and etiological agents may not be accepted unless they have been rendered nonhazardous by disinfecting or sterilization. 
Appendix C

Waste Stream Summary for the Accelerated Retrieval Project 


\section{Appendix C}

\section{Waste Stream Summary for the Accelerated Retrieval Project}

Table C- 1 contains a list of the waste estimated to be generated during the ARP, including construction, operation, and interim closure. 
Table C-1. Waste stream summary for the Accelerated Retrieval Project.

\begin{tabular}{|c|c|c|c|c|c|}
\hline Waste Stream Description & $\begin{array}{l}\text { Estimated } \\
\text { Volume }\end{array}$ & $\begin{array}{c}\text { Container Type } \\
\text { and Quantity }\end{array}$ & Expected Type(s) ${ }^{\mathrm{a}}$ & $\begin{array}{c}\text { Storage or } \\
\text { Staging Location } \\
\end{array}$ & Planned Disposition \\
\hline \multicolumn{6}{|c|}{ Construction Phase } \\
\hline $\begin{array}{l}\text { Construction debris-(other) } \\
\text { wood, plastics, and paper }\end{array}$ & $\mathrm{NE}$ & NA & IW & $\begin{array}{l}\text { Construction debris } \\
\text { dumpster }\end{array}$ & $\begin{array}{l}\text { Recycling or INL Landfill } \\
\text { Complex. }\end{array}$ \\
\hline \multicolumn{6}{|c|}{ Operations Phase-Waste From Inside the Retrieval Enclosure or Airlock Enclosures } \\
\hline $\begin{array}{l}\text { PPE that has come in contact } \\
\text { with waste from the pit } \\
\text { (e.g., respirators, air lines, leather } \\
\text { gloves, and safety clothing) }\end{array}$ & $500 \mathrm{~m}^{3}$ & $\begin{array}{l}\text { Soft-sided bags, soil } \\
\text { sacks, bags, and } \\
\text { drums }\end{array}$ & CERCLA & $\begin{array}{l}\text { Staged in the retrieval area } \\
\text { or airlocks }\end{array}$ & $\begin{array}{l}\text { Disposal in the pit or ICDF for } \\
\text { waste generated and packaged in } \\
\text { containers for off-INL Site } \\
\text { disposal. }\end{array}$ \\
\hline
\end{tabular}


Table C-1. (continued).

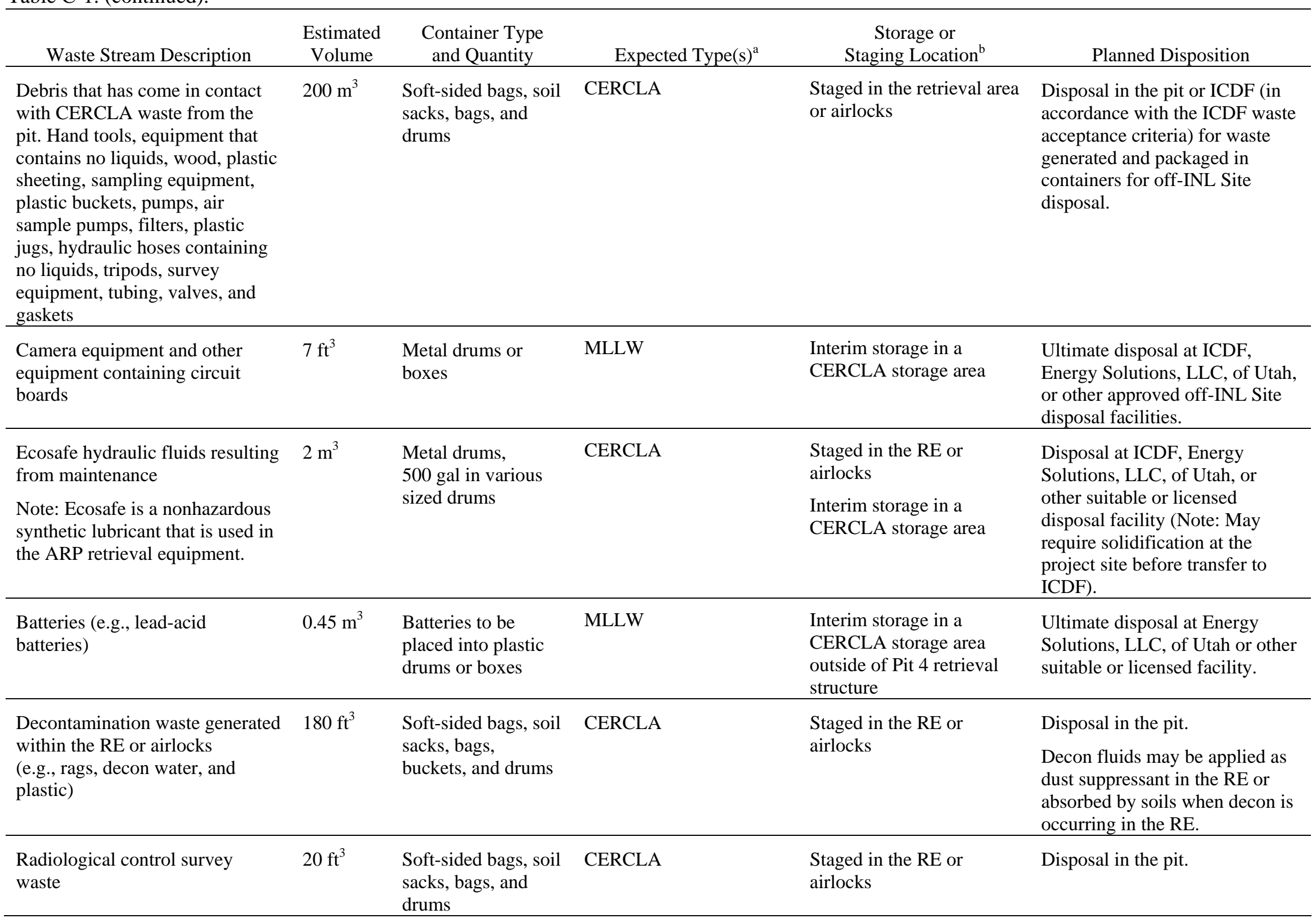


Table C-1. (continued).

\begin{tabular}{|c|c|c|c|c|c|}
\hline Waste Stream Description & $\begin{array}{l}\text { Estimated } \\
\text { Volume }\end{array}$ & $\begin{array}{l}\text { Container Type } \\
\text { and Quantity }\end{array}$ & Expected Type(s) $)^{\mathrm{a}}$ & $\begin{array}{c}\text { Storage or } \\
\text { Staging Location }\end{array}$ & Planned Disposition \\
\hline $\begin{array}{l}\text { Spill waste-nonhazardous fluid } \\
\text { spills within the RE (e.g., } \\
\text { hydraulic fluids that leak from } \\
\text { the excavator/fork lift inside the } \\
\text { retrieval structure) }\end{array}$ & $\mathrm{NE}$ & $\mathrm{NE}$ & NA & NA & $\begin{array}{l}\text { Nonhazardous fluid spills will be } \\
\text { allowed to absorb into the soil if } \\
\text { released within the RE. }\end{array}$ \\
\hline \multicolumn{6}{|c|}{ Operations Phase-Waste From Outside the Retrieval Enclosure or Airlock Enclosures } \\
\hline Used parts from maintenance & $20 \mathrm{ft}^{3}$ & $\begin{array}{l}\text { Three } \\
\text { 55-gal drums }\end{array}$ & IW & Clean waste receptacles & $\begin{array}{l}\text { INL Landfill Complex after } \\
\text { survey release. }\end{array}$ \\
\hline $\begin{array}{l}\text { Administrative waste (e.g., paper, } \\
\text { tape, and pens) }\end{array}$ & $30 \mathrm{ft}^{3}$ & $\begin{array}{l}\text { Four } \\
\text { 55-gal drums }\end{array}$ & IW & Clean waste receptacles & $\begin{array}{l}\text { INL Landfill Complex after } \\
\text { survey release. }\end{array}$ \\
\hline Spill waste-hazardous materials & $\mathrm{NE}$ & $\mathrm{NE}$ & HW & RWMC CERCLA storage & INL contract for HW disposal. \\
\hline Light bulbs & $\mathrm{NE}$ & $\mathrm{NE}$ & IW or UW & $\begin{array}{l}\text { Clean waste receptacles or } \\
\text { RWMC accumulation area } \\
\text { for UW bulbs }\end{array}$ & $\begin{array}{l}\text { INL Landfill Complex or INL } \\
\text { contract for UW disposal. }\end{array}$ \\
\hline Batteries & $\mathrm{NE}$ & $\mathrm{NE}$ & IW or UW & $\begin{array}{l}\text { Clean waste receptacles or } \\
\text { RWMC accumulation area } \\
\text { for batteries if UW }\end{array}$ & $\begin{array}{l}\text { INL Landfill Complex or INL } \\
\text { contract for UW disposal. }\end{array}$ \\
\hline
\end{tabular}


Table C-1. (continued).

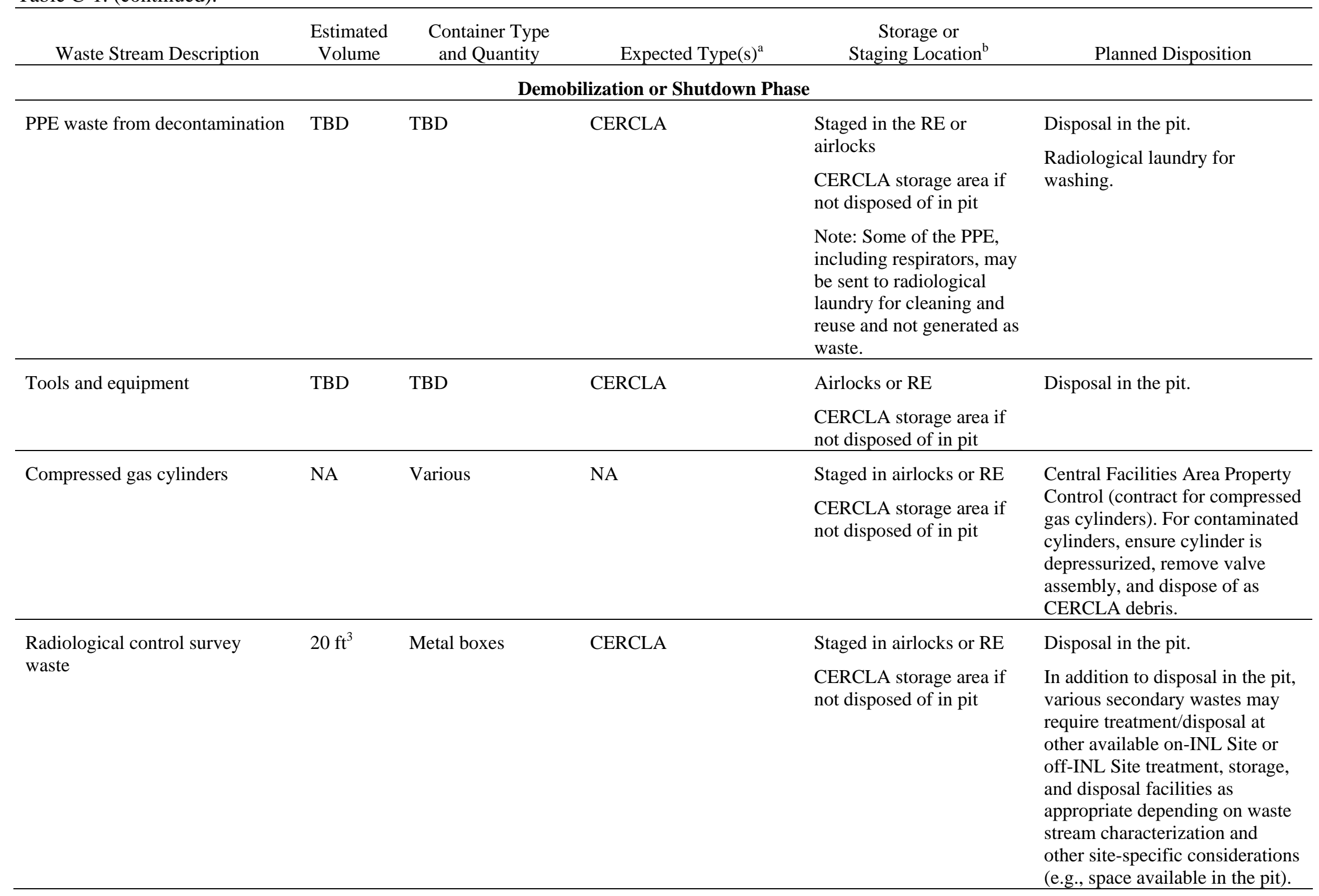


Table C-1. (continued).

\begin{tabular}{|c|c|c|c|c|c|}
\hline Waste Stream Description & $\begin{array}{l}\text { Estimated } \\
\text { Volume }\end{array}$ & $\begin{array}{c}\text { Container Type } \\
\text { and Quantity }\end{array}$ & Expected Type(s) $^{\mathrm{a}}$ & $\begin{array}{c}\text { Storage or } \\
\text { Staging Location }^{\mathrm{b}}\end{array}$ & Planned Disposition \\
\hline $\begin{array}{l}\text { Facility structural components } \\
\text { (e.g., building liners and } \\
\text { foundation blocks) }\end{array}$ & TBD & TBD & CERCLA & $\begin{array}{l}\text { Staged in RE or airlocks } \\
\text { CERCLA storage area if } \\
\text { not disposed of in pit }\end{array}$ & Disposal in the pit. \\
\hline \multicolumn{6}{|c|}{$\begin{array}{l}\text { a. Expected waste types: MTRU = mixed transuranic waste; MLLW = mixed low-level waste; IW = industrial waste; UW = universal waste; HW = hazardous waste, CERCLA = Comprehensive } \\
\text { Environmental Response, Compensation, and Liability Act; and low-level waste. } \\
\text { b. Secondary wastes to be returned to the original excavation may be staged temporarily within the RE and airlocks before disposal in the pit. Secondary waste is not eligible for disposal in the pit in the } \\
\text { event the waste is managed in a manner that constitutes placement of the waste, and by Agency agreement, that are managed outside of the RE or airlocks. }\end{array}$} \\
\hline $\begin{array}{l}\text { ARP = Accelerated Retrieval Project } \\
\text { CERCLA = Comprehensive Environm } \\
\text { ICDF = Idaho CERCLA Disposal Fac } \\
\text { INL = Idaho National Laboratory } \\
\text { NA = not applicable } \\
\text { NE = not estimated } \\
\text { PPE = personal protective equipment } \\
\text { RE = Retrieval Enclosure } \\
\text { RWMC = Radioactive Waste Manage } \\
\text { TBD = to be determined based on lack } \\
\text { WIPP = Waste Isolation Pilot Plant }\end{array}$ & $\begin{array}{l}\text { Response, Con } \\
\text { Complex } \\
\text { rrent detailed p }\end{array}$ & $\begin{array}{l}\text { gensation, and Liability } \\
\text { anning to support definit }\end{array}$ & & & \\
\hline
\end{tabular}


Appendix D

Inspection Checklist 


\section{Appendix D}

\section{Inspection Checklist}

\begin{tabular}{|c|c|c|c|}
\hline \multirow[b]{2}{*}{ Criteria $^{a}$} & \multicolumn{2}{|c|}{ Status ${ }^{\mathrm{b}}$} & \multirow[b]{2}{*}{ Comments } \\
\hline & \begin{tabular}{l|l}
$\mathrm{S}$ & $\mathrm{U}$ \\
\end{tabular} & $\mathrm{N}$ & \\
\hline \multicolumn{4}{|c|}{ Weekly } \\
\hline \multicolumn{4}{|l|}{$\begin{array}{l}\text { Leaks/Spills: Visually inspect WMF-698 to ensure } \\
\text { there are no visible signs of leaks or spills. If liquids } \\
\text { or other potential hazardous or mixed waste are found } \\
\text { on a container, pallet, or on the floor, then initiate } \\
\text { corrective action. }\end{array}$} \\
\hline \multicolumn{4}{|l|}{$\begin{array}{l}\text { Leaks/Spills: Visually inspect the other CERCLA } \\
\text { storage areas to ensure there are no visible signs of } \\
\text { leaks or spills. If liquids (other than precipitation) or } \\
\text { other potential hazardous or mixed waste are found on } \\
\text { a container, pallet, or on the floor, then initiate } \\
\text { corrective action. }\end{array}$} \\
\hline \multicolumn{4}{|l|}{$\begin{array}{l}\text { Secondary Containment: Visually inspect WMF-698 } \\
\text { to verify that no liquid is present in the containment } \\
\text { system of the spill pallet/pan. }\end{array}$} \\
\hline \multicolumn{4}{|l|}{$\begin{array}{l}\text { Secondary Containment: Visually inspect the other } \\
\text { CERCLA storage areas to verify that no liquid is } \\
\text { present in the containment system of the spill } \\
\text { pallet/pan. }\end{array}$} \\
\hline \multicolumn{4}{|l|}{$\begin{array}{l}\text { Radiological Survey: Collect a swipe from any } \\
\text { spill/leak or from any container observed with damage } \\
\text { that could impact container integrity. }\end{array}$} \\
\hline \multicolumn{4}{|c|}{ Monthly Inspections } \\
\hline \multicolumn{4}{|l|}{$\begin{array}{l}\text { Secondary Containment: Inspect spill pallets/pans in } \\
\text { WMF-698 looking for evidence of significant cracks } \\
\text { and gaps that may compromise the integrity of the } \\
\text { containment. }\end{array}$} \\
\hline \multicolumn{4}{|l|}{$\begin{array}{l}\text { Secondary Containment: Inspect spill pallets/pans in } \\
\text { the other CERCLA storage areas looking for evidence } \\
\text { of significant cracks and gaps that may compromise } \\
\text { the integrity of the containment. This inspection will } \\
\text { be performed around the perimeter of the container } \\
\text { rows and down the central aisle. }\end{array}$} \\
\hline \multicolumn{4}{|l|}{$\begin{array}{l}\text { Fire Extinguishers: Visually inspect fire extinguishers } \\
\text { to ensure they are in the proper location, easily } \\
\text { accessible, and that there is no evidence of damage or } \\
\text { tampering. }\end{array}$} \\
\hline $\begin{array}{l}\text { Spill Control: Visually inspect spill control equipment } \\
\text { and the contents of the equipment. }\end{array}$ & & & \\
\hline
\end{tabular}




\begin{tabular}{|c|c|c|c|c|}
\hline \multirow[b]{2}{*}{ Criteria $^{a}$} & \multicolumn{3}{|c|}{ Status ${ }^{\mathrm{b}}$} & \multirow[b]{2}{*}{ Comments } \\
\hline & $\mathrm{S}$ & $\mathrm{U}$ & $\mathrm{N}$ & \\
\hline \multicolumn{5}{|c|}{ Quarterly Inspection } \\
\hline $\begin{array}{l}\text { Leaks/Spills: Visually inspect WMF- } 698 \text { for any } \\
\text { liquid present on or near the containers and for signs } \\
\text { of defective, visibly pitted, metal-fatigued, or } \\
\text { deteriorated containers. This inspection will be } \\
\text { performed around the perimeter of the container rows } \\
\text { and through each aisle in between the rows of } \\
\text { containers. }\end{array}$ & & & & \\
\hline $\begin{array}{l}\text { Radiological Survey: Collect a swipe from any } \\
\text { spill/leak or from any container observed with damage } \\
\text { that could impact container integrity. }\end{array}$ & & & & \\
\hline $\begin{array}{l}\text { Storage Configuration: Verify that containers in } \\
\text { WMF- } 698 \text { are positioned properly and properly } \\
\text { located in the storage configuration. Rows of drums in } \\
\text { WMF- } 698 \text { are no more than } 4 \text { drums wide by } 5 \text { drums } \\
\text { high by } 28 \text { drums in length. }\end{array}$ & & & & \\
\hline \multicolumn{4}{|c|}{$\begin{array}{l}\text { a. Containment inspection requirements are included as a contingency action in the event } \\
\text { containment. } \\
\text { b. S = Satisfactory } \\
\qquad \mathrm{U}=\text { Unsatisfactory } \\
\quad \mathrm{N}=\text { Not Applicable } \\
\text { CERCLA = Comprehensive Environmental Response, Compensation, and Liability Act }\end{array}$} & equire storage in \\
\hline
\end{tabular}

